$1-1-1926$

\title{
Correlated Inheritance of Quantitative and Qualitative Characters in Oats
}

Karl S. Quisenberry

Follow this and additional works at: https://researchrepository.wvu.edu/ wv_agricultural_and_forestry_experiment_station_bulletins

\section{Digital Commons Citation}

Quisenberry, Karl S., "Correlated Inheritance of Quantitative and Qualitative Characters in Oats" (1926). West Virginia Agricultural and Forestry Experiment Station Bulletins. 202.

https://researchrepository.wvu.edu/wv_agricultural_and_forestry_experiment_station_bulletins/202 
West Virginia University Libraries 
EVASOALE LIBRARY

WEST VRGINA

UMUERSIT 
Restricted

Circulation Only

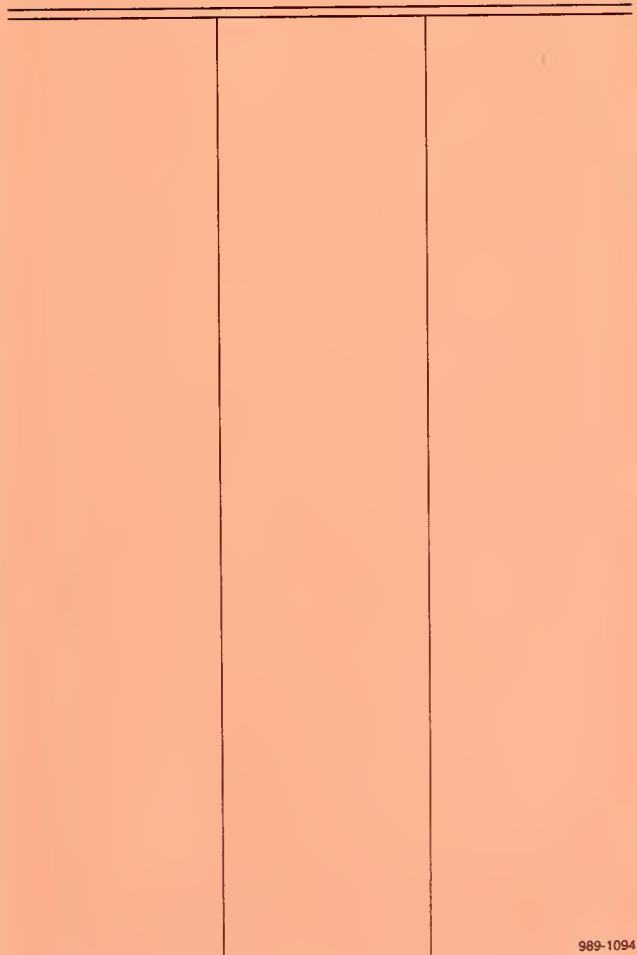





\section{Aqricultural Experiment Station}

College of Agriculture, Jeat Virginia fHnibersity

HENRY G. KNIGHT, Director

Morgantown

Correlated Inheritance of Quantitative and Qualitative Char-

\section{acters in Oats}

(Technical)

\section{By}

KARL S. QUISENBERRY 


\section{AGRICULTURAL EXPERIMENT STATION STAFF}

FRANK BUTLER TROTTER, A. M., LL. D. -......President of the University HENRY G. KNIGHT, Ph. D._._._._. Dean of the College of Agriculture and Director of the Experiment Station

WALTER C. SCHNOPP, B. S. Agr._-_._. Agricultural Editor JOHN C. JOHNSTON

Chief Clerk

\section{AGRONOMY}

R. J. Garber, Ph. D.

T. E. Odland, Ph. D.

Agronomist

D. R. Dodd, M. S.

Associate Agronomist

Assistant Agronomist

T. C. Mcllvaine, Ph. D.*广

M. M. Hoover, M. S.

Assistant Agronomist

H. K. Rowley, B. S. Agr.**

$$
\text { Junior Agronomist }
$$

ANIMAL HUSBANDRY

Seed Analyst

E. A. Livesay, M. S.

Animal Husbandman

Chas. V. Wilson, M. S.

Assistant Animal Husbandman

E. C. Stilwell, M. S.

Assistant Animal Husbandman

R. H. Tuckwiller, B. S. Agr.*

Assistant Animal Husbandman

\section{CHEMISTRY}

R. B. Dustman, Ph. D.

Associate Chemist

Chas. E. Weakley, Jr., B. A.

Assistant Chemist

T. B. Leith, B. A.**

T. J. Cochrane, M. S.

Assistant Chemist

Paul Daughenbaugh

Junior Chemist

\section{DAIRY HUSBANDRY}

Assistant in Chemistry

E. L. Anthony, M. S. Agr.

Dairy Husbandmau

H. O. Henderson, M. S. Agr.

Associate Dairy Husbandman

G. Malcolm Trout, M. S.

Junior Dairy Husbandman

\section{ENTOMOLOGY}

L. M. Peairs, Ph. D.

W. E. Rumsey, B. S.**

Entomologist

L. E. Dills, B. S.**

State Entomologisi

Assistant in Entomology

\section{ZOOLOGY}

F. E. Chidester, Ph. D.
FARM ECONOMICS

A. J. Dadisman, $\mathrm{Ph}$. D.

Paul A. Eke, Ph. D.

Assistant Farm Economist

F. D. Cornell, Jr., M. S.

Junior Farm Mechanician

W. W. Armentrout, M. S.

Junior Farm Economist

HOME ECONOMICS

Ruth Buchanan, Ph. D.

Nell Nesbitt, A. M.

Home Economist

Home Management Specialist

HORTICULTURE

H. L. Crane, M. S. Agr.

Horticulturist

Associate Horticulturist

H. E. Knowlton, Ph. D.

Associate Horticulturist

K. C. Westover, M. S. Agr.

Assistant Horticulturist

Ernest Angelo, M. S. Agr.

Junior Horticulturist

L. F. Sutton, B. S. Agr.t

Assistant Horticulturist

H. P. Sevy, B. S. Agr.

Assistant in Horticulture

A. L. Tener, B. S.

Assistant in Horticulture

PLANT PATHOLOGY

N. J. Giddings, Ph. D.

Anthony Berg, M. S.

Plant Pathologist

Assistant Plant Pathologist

L. H. Leonian, Ph. D.

Assistant Plant Pathologist

E. C. Sherwood, M. S.

Assistant Plant Pathologist

POULTRY HUSBANDRY

Horace Atwood, M. S. Agr.

Poultry Husbandman SOILS

E. P. Deatrick, Ph. D.

Associate Soil Technologist

RURAL SOCIOLOGY

T. L. Harris, Ph. D. 


\section{CONTENTS}

INTRODUCTION

LITERATURE REVIEW

General Methods Used in the Study of

Inheritance of Quantitative Characters

Quantitative Inheritance in Oats

MATERIALS AND METHODS - 7

Description of Parents

Method of Growing Material _._. 8

Technique of Sampling _. 9

Size of Sample

Variation of Length of Grain at Different

Places on the Panicle

Variability of Grain Length of Parents

Influence of Soil Condition on Length of Grain _..._. 12

Variation of Grain Length of Parental Varieties in Check Plots_-- 13

INHERITANCE OF CHARACTER DIFFERENCES

Length of Grain _._._. 14

Color of Grain

Panicle Type

Degree of Awn Development

CORRELATED INHERITANCE OF CHARACTERS _._. 26

Relation of Length of Grain and Color of Grain

Relation of Length of Grain and Panicle Type

Relation of Length of Grain and Awn Development _-_-_-_-_-_-_-_ 28

Relation of Color of Grain and Panicle Type

Relation of Grain Color and Awn Development _-_._._._._._._. 31

Relation of Panicle Type and Awn Development

DISCUSSION OF RESULTS

SUMMARY

LITERATURE CITATIONS

APPENDIX - 
Digitized by the Internet Archive in 2010 with funding from

Lyrasis Members and Sloan Foundation 


\section{Correlated Inheritance of Quantative and Qualitative Characters In Oats*}

The inheritance of quantitative characters, while of much interest irom a practical as well as a scientific standpoint, has not been studied as extensively as that of qualitative characters. It is well known, however, that size characters are often very coniplex in their mode of inheritance, and frequently environment may cause rer:tions completely covering the effects of heredity. Because of this apparent complexity of inheritance, some geneticists formerly held that the laws formulated by Mendel did not hold for size characters. It is realized now that, as a rule, most, if not all, normal characters are the result of the interaction of many factors plus environment. East, Hayes, Emerson, and others, have furnished much evidence which proves that the inheritance of quantitative and qualitative characters can be explained on the same genetic basis.

\section{LITERATURE REVIEW}

\section{General Methods Used in the Study of Inheritance of}

\section{Quantitative Characters}

The studies of the inheritance of size characters have been conducted in such a way as to determine whether certain mathematical requirements, as outlined by East (1916), were fulfilled. These requirements are, briefly, as follows:

1.-Crosses between homozygous individuals should give $F_{1}$ populations comparable to the parental races in uniformity.

2.-If the parents were homozygous, $F_{2}$ frequency distributions arising from extreme variants of the $F_{1}$ population should be identical, since the variation in $\mathrm{F}_{1}$ should be due to environmental conditions.

3.-The variability of the $\mathrm{F}_{2}$ population should be much greater than that of the $F_{1}$ population.

*The manuscript of this bulletin, with slight modifications, was presented to the Graduate Faculty, University of Minnesota, in partial fulfilment of the requirements for the degree of Master of Science in June, 1925. The writer takes this opportunity to acknowledge the aid of various people in the preparation of this paper. Dr. H. K. Hayes, Professor of Plant Breeding, University of Minnesota, under whose direction the manuscript was prepared, gave valuable criticism and advice in the analysis of the data and the manner of presentation. Dr. R. J. Garber, Head of the Department of Agronomy, University of West Virginia, gave helpful advice in outlining the experiment, and in taking the data. Dr. Fred Griffee, Assistant Professor of Plant Breeding, University of Minnesota, made helpfuI suggestions as to the presentation of the data. Julia P. Quisenberry gave very efficient assistance in collecting and preparing the data.

The investigation reported in this bulletin was carried on at the West Virginia Agricultural Experiment Station as a part of a project on oat breeding. At the time this work was done and this manuscript prepared the author was Junior Agronomist in the Department of Agronomy, which position he resigned August 1, 1925. 
4.-If enough $\mathrm{F}_{2}$ individuals are grown, the grand-parental types should be recovered.

5.- In certain cases, individuals should be produced in $\mathrm{F}_{2}$, showing a more extreme deviation than is found in either grand-parent.

6.-Individuals from different points on the frequency curve of the $F_{2}$ population should give $F_{3}$ populations differing markedly in their modes and means.

7.-Individuals either from the same or from different points on the frequency curve of an $F_{2}$ population should give $F_{3}$ populations of diverse variabilities extending from that of the original parents to that of the $F_{2}$ generation.

8.- In generations following the $\mathrm{F}_{2}$, the variability of any family may be less, but never greater than the variability of the population from which it came.

Not all of these points are met in every cross studied, but they have been met many times in the studies made by various plant and animal geneticists and the agreement between the results and the mathematical requirements has, as a rule, been satisfactory.

The studies of linkage relations have furnished a valuable method of attack on the problem. By this method it is possible to study the factor or factors for size, if there be any present, in each known linkage group of a given plant. Such a method leads to a rather accurate determination as to the exact number of factors, or groups of factors, involved in certain size differences.

Sax (1923), working with beans, studied the relation of size of seed to pigmentation of the seed and found that factors, or groups of factors, for seed weight were linked with factors for pigmentation and pattern of the seed coat. In a cross Svanhals with Lion barley, Griffee (1925), studied the relation of resistance to Helminthosporium sativum, and certain morphological characters. He concluded that resistance to this disease was controlled by at least three factors, or groups of factors, apparently linked with the factors determining the character pairs six-rowed versus two-rowed, black versus white glumes, and rough versus smooth awn. The linkage was not complete as resistance or susceptibility could be combined with any desired morphological character. Similarly, Lindstrom (1924) found that in tomatoes small size of fruit was linked with colorless skin.

\section{Quantitative Inheritance in Oats}

Quantitative characters in oats have not been studied very extensively. Hayes and Garber (1921) have summarized the early work of Nilsson-Ehle. Two Avena sativa varieties differing in height 
were crossed and transgressive segregation was obtained in $\mathbf{H}_{2}$. Segregation was of a complex nature. Other crosses were made involving leaf breadth, kernel size, and number of florets to the spikelet. These crosses also gave transgressive segregation, and the results were explained on a multiple factor hypothesis, although the actual factors involuved could not be determined. Nilsson-Ehle obtained transgressive segregation for period of maturity in the $\mathrm{F}_{2}$ of a cross between a medium early and a late maturing variety of oats. Progenies of $112 \mathrm{~F}_{2}$ plants were continued in $\mathrm{F}_{3}$, of which 98 segregated and 14 were homozygous, some being earlier than the early parent, and others later than the late parent.

Caporn (1918) crossed an early variety with a late maturing variety of oats. The $F_{1}$ and $F_{2}$ generations were not studied, but 106 lines were continued in $\mathrm{F}_{3}$. Of the 106 lines continued two were considered to be as early as the early parent, although no lines were as late as the late parent. In twenty-two other lines, ripening extended over a period from the date of ripening of the early parent to that of the late parent. In some of these lines most of the plants ripened the first part of the period, in others the middle part, while in some lines the plants were mostly of late maturity. The remainder of the lines were more or less intermediate as to time of ripening. The results were explained on a three factor basis, the author suggesting that possibl- the two early lines were homozygous for all three factors.

\section{MATI ?IALS AND METHODS}

\section{Description of Parents}

This paper presents the results of a cross between Victor (Avena sativa) and Sparrowbill (Avena sativa orientalis). The object being to study the mode of inheritance of length of the primary grain,* as well as any possible correlations of this character with other differential charac ars of the two parents.

The following desc' tion of the parents is taken from Etheridge (1916). Only those cl-aracters of interest in the present study are included in the descript. in.

Victor._"Panicles long, broad, coarse, wide-spreading, lax, the branches usually drooping from middle outward; spikelets tivograined, three-grained spikelets seldom occuring..... grains black

- Note: In all species of oats other than Avena nuda, the flowering glumes adhere firmly to the grain proper, or caryopsis. The studies reported in this paper have to do with the length and color of flowering glumes of the primary grain, but, instead of referring each time to "fllowering" glumes, the word "grain" will be used to designate caryopsis enclosed in its flowering glumes, This terminology is similar to that used by Surface (1916-7). 
to brownish black, very large and coarse, outer grains usually 18-22 mm. long . . . . . awns usually present, strong, coarse, twisted, often slightly geniculate."

Sparrowbill._- "Panicles thickly branched and fruited, compact, stiff, but sometimes slightly drooping at the apex, the branches appressed,...... spikelets two-grained, rarely three-grained, double grains very frequent, ...... grains white, shading into pale yellow, outer grains remarkably short (12-15 mm.), plump, full,-awns wanting or rare."

The characters studied and the manner in which they entered the cross are given herewith in tabular form:

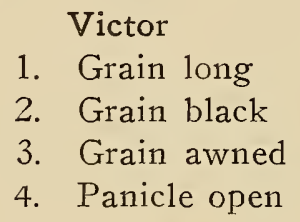

\section{Sparrowbill}

1. Grain short

2. Grain white

3. Grain awnless

4. Panicle side

\section{Method of Growing Material}

The crosses were made in 1922, at the West Virginia Agriculutral Experiment Station. To obtain seed for the crossing plots, an individual panicle was selected from a bundle of pure line material of each parent grown the previous year. All parental material grown in 1923 and 1924 traces back to these two original panicles.

The crossed grains were planted in the greenhouse in the fall of 1922, the $F_{1}$ generation maturing in time for planting in the spring of 1923. The $F_{2}$ generation was grown in 1923, with some additional $F_{1}$ plants and a small amount of parental material. In 1924 , the $F_{3}$ generation was grown, as well as $\mathrm{F}_{1}, \mathrm{~F}_{2}$, and parental material.

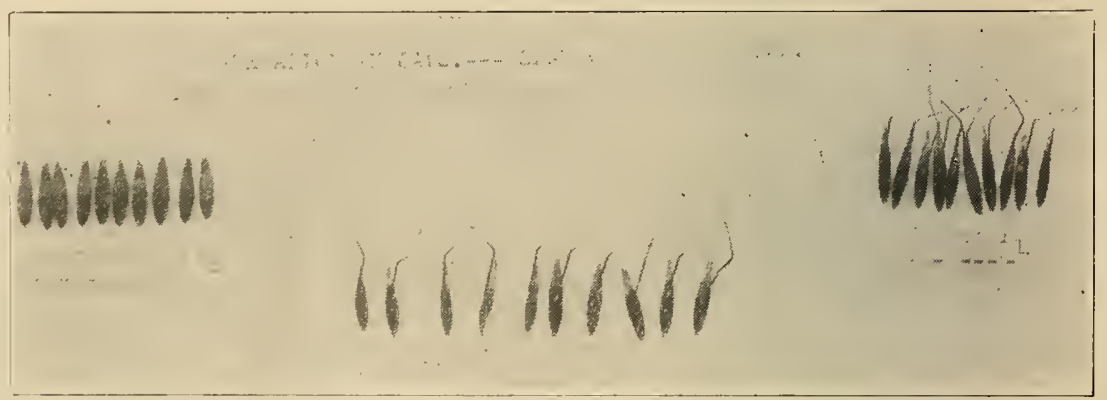

Sparrowbill and Victor Parents, and the $F_{1}$ of the Cross.

Sparrowbill Has Short, White Grains, and is Awnless. Victor Has Long, Black Grains and is Awned. The $F_{1}$ Generation Has Black Grains, is Nearly as Heavily Awned as Victor, and is Intermediate for Grain Length. 
The method of planting was to space the grains every three inches in rows one foot apart. In 1923, twenty grains were planted per row, while, in 1924, the number was increased to twenty-five. At each end of the rows a stake was placed and outside of this stake three grains of the Victor parent were planted to give guard plants, in an attempt to reduce border effect. These border plants were pulled and discarded just before harvest. The $\mathrm{F}_{3}$ lines were grown in plots consisting of two rows each; thus a total of fifty grains were planted. After each five plots of $\mathrm{F}_{3}$ material, one plot of each parent was included, giving check plots at distantces of ten rows apart throughout the experiment.

Germination was poorer than expected in 1924, due to very cool, damp weather immediately following planting; therefore, the number of plants per row was reduced and the distance between plants was not always the same. No correction was attempted to reduce this error, as all $F_{3}$ lines, parents and $F_{2}$ material grown in 1924, were subjected to the same environmental conditions, and all reacted approximately the same.

A large number of plants of each parent were grown on good and poor soil in 1923 and 1924, in order to study the effect of soil condition on length or grain. This material was handled in the same manner as described above for the hybrids and parents.

In all calculations presented in this paper the method followed was to carry figures to one place further beyond the decimal point than is recorded in any of the tables.

\section{Technique of Sampling}

Preliminary to measuring the length of grain of the hybrids, some work was necessary to determine the correct size of sample to measure from each plant or on a single panicle, due to the time required. Not only was it necessary to study the size, but also the manner of taking the sample. No work was done to determine the variation between panicles of the same plant, but, in all cases, the leading panicle of each plant was used. In all cases, the measurements taken were on the primary grain.

\section{Size of Sample}

To determine the size of sample needed to give an accurate measure of the length of grain for a given plant, the following method was used. All the grains from the leading panicle of 117 Victor plants grown on good soil in 1923 were measured. The grains were removed from the panicle in an orderly manner from the base to. the tip of the panicle. These grains were measured and the individual 
lengths recorded in the same order in which they were removed from the panicle.

Samples of five, ten, and fifteen measurements were selected from the data on each panicle, by taking measurements from all parts of the panicle. For example, if a panicle had thirty grains, the sample of five grains was selected by taking the measurement of the fourth, tenth, sixteenth, twenty-second, and twenty-eighth grains. In taking the different size samples, care was exercised so as not to use a given measurement more than once, unless absolutely necessary. The 117 means for a given size sample were placed in frequency distributions, as shown in Table 25 of the appendix. A summary of this data is given in Table 1 .

\section{TABLE 1.-Statistical Constants for Different Size of Samples of Grains Measured on the Leading Panicle of Plants of Victor Oats Grown on Good Soil 1923.}

\begin{tabular}{c|c|c|c}
\hline $\begin{array}{c}\text { Number of } \\
\text { Grains in } \\
\text { Sample }\end{array}$ & $\begin{array}{c}\text { Mean Length of } \\
\text { Grain in Milli- } \\
\text { meters }\end{array}$ & $\begin{array}{c}\text { Standard } \\
\text { Deviation }\end{array}$ & $\begin{array}{c}\text { Probable Error } \\
\text { Single Deter- } \\
\text { mination }\end{array}$ \\
\hline 5 & $17.82 \pm 0.05$ & $0.86 \pm 0.04$ & 0.58 \\
10 & $17.80 \pm 0.06$ & $0.88 \pm 0.04$ & 0.59 \\
15 & $17.79 \pm 0.05$ & $0.84 \pm 0.04$ & 0.56 \\
All Grains & $17.77 \pm 0.05$ & $0.82 \pm 0.04$ & 0.55 \\
\hline
\end{tabular}

In no case is there a difference of practical importance in the means of the sample of five, ten, fifteen, or all of the grains on the panicle. Likewise, the standard deviations are of about the same value. These figures seem to show that, for this experiment, samples of five, ten, or fifteen grains have approximately as accurate a measure of length of grain as that obtained by measuring all the grains in the panicle. It was decided to measure a sample of ten grains from the main panicle of each plant.

Variation of Length of Grain at Different Places on the Panicle.For this study plants of the Victor parent grown on good soil were used. As stated previously, the grains from the panicles were removed in order, the measurements also being recorded in order. To determine if there was any increase in length of grain in one part of the panicle over another, the measurements were grouped by fives from the base to the tip of the panicle, and the means determined for each of these groups. Panicles with approximately the same number of grains were compared and the means for the average measurements of the first, second, third, etc., groups from the bottom were 
determined. These data are presented in Table 26 of the appendix. This table also gives the number of groups, the number of plants going to make up the mean, the approximate number of grains per panicle, and the mean length for the group with its probable error. The number of grains per panicle varied from fifteen to fifty; no panicles being included unless they contained at least fifteen grains. In all cases only full groups of five grains were considered. For example, if a panicle had twenty-eight grains, five groups were taken, the three grains at the tip being disregarded.

The number of plants with different sized panicles ranged from nine with three groups of five grains each, to twenty-one with six and seven groups each. The probable errors of the means were determined by Bessel's formula,* and all are of nearly the same value.

In order to determine if there was a significant increase in length of grain as the tip of the panicle was approached considering all of thc plants, comparisons were made between the first and mid group, mid and last group, and the first and last group. In this comparison Student's method was used to calculate the probabilities. These zalculations will be found in Table 2 . The first column gives the number of groups per panicle; the other columns indicate the difference in length between the first and mid group, mid and last, or

rABLE 2.-Differences in Mean Length of Grains Between the First, Mid, and Last Groups on the Panicle. Probabilities Calculated According to Student's Method. Victor Parent Grown on Good Ground 1923.

\begin{tabular}{|c|c|c|c|}
\hline \multirow[b]{2}{*}{$\begin{array}{c}\text { Number of } \\
\text { Groups on the } \\
\text { Panicle }\end{array}$} & \multicolumn{3}{|c|}{ Difference in Millimeters Between } \\
\hline & $\begin{array}{l}\text { First } \\
\text { and Mid } \\
\text { Group }\end{array}$ & $\begin{array}{l}\text { Mid } \\
\text { and Last } \\
\text { Group }\end{array}$ & $\begin{array}{l}\text { First } \\
\text { and Last } \\
\text { Group }\end{array}$ \\
\hline $\begin{array}{r}3 \\
4 \\
5 \\
6 \\
7 \\
8 \\
9 \\
10\end{array}$ & $\begin{array}{r}+0.10 \\
+0.35 \\
+0.20 \\
+0.05 \\
+0.60 \\
+0.35 \\
+0.30 \\
+0.55\end{array}$ & $\begin{array}{r}+1.00 \\
+0.65 \\
+0.80 \\
+1.05 \\
+0.60 \\
+0.95 \\
+0.60 \\
+0.15\end{array}$ & $\begin{array}{r}+1.10 \\
+1.00 \\
+1.00 \\
+1.10 \\
+1.20 \\
+1.30 \\
+0.90 \\
+0.70\end{array}$ \\
\hline $\begin{array}{l}\text { lean Difference } \\
\text { of Dierence } \\
\text { alue of } \mathrm{Z} \\
\text { dds }\end{array}$ & $\begin{array}{r}+0.31 \\
0.18 \\
1.72 \\
765: 1\end{array}$ & $\begin{array}{c}+0.73 \\
0.28 \\
2.61 \\
\text { Significant }\end{array}$ & $\begin{array}{c}+1.04 \\
0.17 \\
6.12 \\
\text { Significant }\end{array}$ \\
\hline
\end{tabular}

$* \pm .6745 \sqrt{\frac{\Sigma \mathrm{d}^{2}}{\mathrm{n}(\mathrm{n}-1)}}$ 
first and last groups. In the panicles having an even number of groups, the figure for the mid group was the mean of the two mid groups.

In all cases the differences are plus; in other words, the grains are longer nearer the top of the panicle. Comparing the mean differences, it is seen that there is greater increase between the mid and last groups than between the first and mid groups. Using Student's method, the value of $Z^{*}$ was calculated. Referring to the tables prepared by Love (1924) for the $Z$ values, the odds are $765: 1$ against a difference as great as the one shown between the first and mid groups being due to chance. Between the mid and last groups, the chances are over 9,999:1 against as great a difference as the one shown being due to chance, while for the first and last group, the value of $Z$ is more than two times that of the second case; therefore, the difference is certainly significant.

Under the conditions of the experiment it is shown that there is a gradual increase in length of grain from the base to the tip of the panicle and that this increase is greater from the middle part to the tip than from the base to the middle.

From these results it was decided to select the samples of 10 grains at random from all parts of the panicle.

\section{Variability of Grain Length of Parents}

Influence of Soil Condition on Length of Grain.-In order to determine what effect, if any, the productivity of the soil has upon the length of grain, each parent was grown on good and poor soil in 1923 and 1924. The plot designated as "good" was a productive piece of ground, on which previous crops had been making very good growth. During the winter, a heavy application of manure was applied and, just before planting each spring, acid phosphate at the rate of 200 pounds per acre was added. The "poor" plot in 1923 was on some very thin, rocky soil on which previous crops had been very poor. No manure or fertilizer was added. In 1924, the poor plot was in a location which seemed to be in a less productive condition than the plot used in 1923.

In 1923, 240 grains were planted for each parent, while the number of plants harvested varied from 117 to 143 . In 1924, 300 grains were planted and the number of plants harvested ranged from 206 to 232 .

As a check on the vigor of the plants the individual plant heights and yields were taken. These data are given in Table 3 .

Considering Table 3 , it is apparent that the grain length of the Victor parent was little influenced by soil condition in 1923, the dif-

$$
\because \mathrm{z}=\frac{\mathrm{m}}{\sigma}
$$


ference being only about twice the probable error. In 1924, the grain length of the Victor parent was $0.44 \pm 0.04$ millimeters less on poor soil than on good soil. This difference is 11 times the probable error and the odds that a difference as great as this is not due to random sampling are very great.

TABLE 3.-Comparison of Victor and Sparrowbill Parents Grown on Good and Poor Soil, 1923-1924.

\begin{tabular}{|c|c|c|c|c|c|}
\hline Parent & Soil & Year & $\begin{array}{l}\text { Length } \\
\text { of Graln } \\
\text { in } \mathrm{mm} .\end{array}$ & $\begin{array}{c}\text { Yield per } \\
\text { Plant in } \\
\text { gms. }\end{array}$ & $\begin{array}{c}\text { Height of } \\
\text { Plant In } \\
\mathrm{cm} \text {. }\end{array}$ \\
\hline Victor & $\begin{array}{l}\text { Good } \\
\text { Poor }\end{array}$ & 1923 & $\begin{array}{l}17.80 \pm 0.06 \\
17.96 \pm 0.05\end{array}$ & $\begin{array}{l}5.89 \pm 0.21 \\
4.07 \pm 0.10\end{array}$ & $\begin{array}{r}109.12 \pm 0.50 \\
93.44 \pm 0.40\end{array}$ \\
\hline Victor & $\begin{array}{l}\text { Good } \\
\text { Poor }\end{array}$ & 1924 & $\begin{array}{l}17.14 \pm 0.03 \\
16.70 \pm 0.03\end{array}$ & $\begin{array}{l}3.97 \pm 0.09 \\
3.55 \pm 0.06\end{array}$ & $\begin{array}{r}109.03 \pm 0.32 \\
98.78 \pm 0.30\end{array}$ \\
\hline $\begin{array}{r}\text { Sparrow- } \\
\text { bill }\end{array}$ & $\begin{array}{l}\text { Good } \\
\text { Poor }\end{array}$ & 1923 & $\begin{array}{l}13.23 \pm 0.03 \\
13.37 \pm 0.02\end{array}$ & $\begin{array}{l}5.93 \pm 0.21 \\
2.83 \pm 0.10\end{array}$ & $\begin{array}{r}109.76 \pm 0.60 \\
86.76 \pm 0.61\end{array}$ \\
\hline $\begin{array}{r}\text { Sparrow- } \\
\text { bill }\end{array}$ & $\begin{array}{l}\text { Good } \\
\text { Poor }\end{array}$ & 1924 & $\begin{array}{l}12.15 \pm 0.02 \\
12.21 \pm 0.02\end{array}$ & $\begin{array}{l}4.47 \pm 0.09 \\
3.75 \pm 0.07\end{array}$ & $\begin{array}{l}112.68 \pm 0.33 \\
100.00 \pm 0.41\end{array}$ \\
\hline
\end{tabular}

For the Sparrowbill parent there was little difference on the wo soil types in the results obtained for length of grain. The poor lot gave grains $0.14 \pm 0.04$ millimeters longer than the good plot. I his difference is 3.5 times the probable error, the odds being about i4:1 that a difference as great as this is not due to random sampling, lithough the actual increase in length is very small. In 1924, the lifference in the results obtained on the two plots is very small and lot significant.

The data on height and yield of individuals are included for the urpose of giving an indication of the productivity of the two plots. The results obtained prove conclusively that there was considerable lifference between the plots. From this it was concluded that length if grain, while showing some variability due to soil productivity, ras not as greatly influenced as such characters as yield and height i plant.

Variation of Grain Length of Parental Varieties in Check Plots.$t$ has been learned that soil conditions have some influence on length f grain. Tables 27 and 28, presented in the appendix, give the data $n$ the various plots of each parent grown as check plots in 1924.

A study of the means and their probable errors given in these wo tables indicates that there are deviations between the various 
plots of the same parents, which, in the light of their probable errors, are mathematically significant.

To study the extent of soil heterogeneity of the plot on which the hybrids and parents were grown, several correlations were made. The parents were grown in adjacent plots and were distributed uniformly throughout the experimental field at distances apart of ten rows. In each parent the average length of grain of the plants of the first plot and those of the second, the second with the third plot, etc., were correlated. For the Victor parent $r=+0.376 \pm 0.112$ and for Sparrowbill $\mathrm{r}=+0.374 \pm 0.114$. The correlations are of nearly the same magnitude and are both slightly more than three times their probable errors. By reducing the means of the various plots of the parents to a percentage basis, it was possible to place the data of both parents in the same correlation table, thus doubling the number of individuals and reducing the probable error. By this method $r=+0.377 \pm 0.079$. By using the standard error of estimate* a correlation of this magnitude indicates that, for plots ten rows apart, soil heterogeneity affects total variability of length of grain 7.4 per cent. Since the parents were grown in paired plots, it was possible to correlate the grain length of the plants of one parent plot with that of the other. For such a comparison $r=-0.134 \pm 0.110$, indicating no correlation. The fact that there is no correlation between grain length of one parent and the other in adjacent plots shows that the two varieties do not react the same to soil variations.

In order to determine if the actual stand per plot must be considered, the number of plants per plot which survived was correlated with mean length of grain per plot. In Victor $r=+0.105 \pm 0.111$ showing no significant correlation; while, for Sparrowbill, $r=-0.573$ \pm 0.076 , showing that a reduced number of plants tend to allow an increase in length of grain. In both cases the number of variates entering these correlations are quite small, being only thirty-six individuals. It would seem that the number of plants per plot influences the variability of length of grain in Sparrowbill about 18 per cent. This shows the desirability of having approximately the same number of plants in each plot.

\section{INHERITANCE OF CHARACTER DIFFERENCES}

\section{Length of Grain}

A summary of the data for segregation of length of grain in the $F_{1}$ and $F_{2}$ generations of the cross Sparrowbill with Victor and reciprocal is given in Table 4 . Included in this table are the data for

* $100 \times 1-\sqrt{1-r^{2}}$ 


\begin{tabular}{|c|c|c|c|c|c|c|}
\hline 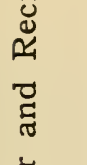 & 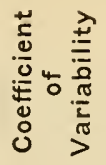 & 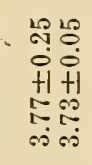 & $\begin{array}{l}-10 \\
0 \\
0 \\
+1 \\
+1 \\
\infty \\
\infty \\
\infty\end{array}$ & & 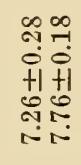 & 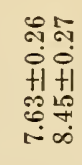 \\
\hline$\stackrel{5}{\sharp}$ & 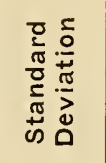 & 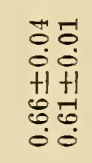 & $\begin{array}{l}30 \\
0 \\
0 \\
0 \\
+1 \\
\infty \\
\infty \\
+1 \\
0 \\
0 \\
0\end{array}$ & & 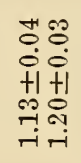 & 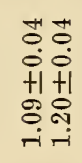 \\
\hline $\begin{array}{l}5 \\
0 \\
3 \\
3 \\
3 \\
3 \\
0 \\
0\end{array}$ & 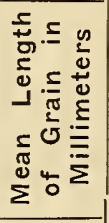 & 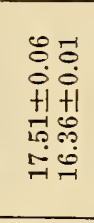 & 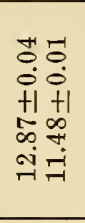 & & $\begin{array}{l}00 \\
80 \\
00 \\
+1+1 \\
500 \\
100 \\
100 \\
10\end{array}$ & 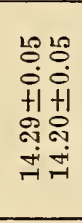 \\
\hline कृ & $\begin{array}{l}\bar{\pi} \\
+\frac{n}{0} \\
F\end{array}$ & ณ & 용 & N N & 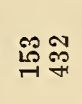 & 䨍 \\
\hline & $\cong \quad \stackrel{\sigma}{=}$ & मन & & & तथ & -1 \\
\hline & $\bar{\pi}$ & 유 요 & & & $m$ 익 & \\
\hline r & \pm & 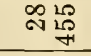 & & & 노요 & FL \\
\hline & \begin{tabular}{lll}
0 & $n$ & 0 \\
\multicolumn{1}{c}{} & 0 & 0
\end{tabular} & 武 & & ज Nন & זم & 'พู \\
\hline & 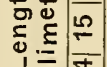 & เึ & & N & Fig & 跑 \\
\hline & 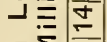 & & 44 & & तु & $76 \infty$ \\
\hline & 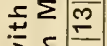 & & 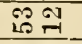 & & $+\infty$ & 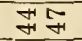 \\
\hline in & $\bar{B} . \equiv \cong$ & & 굥 & & $न-1$ & $\sqrt{20}$ \\
\hline & 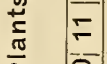 & & $\begin{array}{r}\text { กิ } \\
\text { ชื }\end{array}$ & & & \\
\hline م & $\bar{a} \quad 0$ & $\therefore$ & a & & & \\
\hline · & 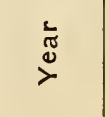 & 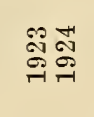 & 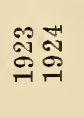 & 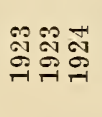 & 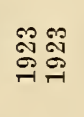 & 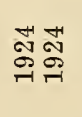 \\
\hline 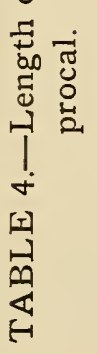 & $\stackrel{\stackrel{\varepsilon}{\pi}}{z}^{0}$ & 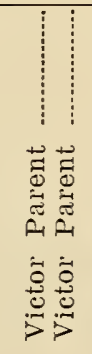 & 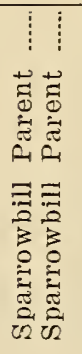 & 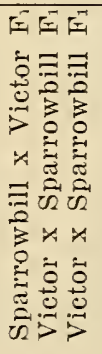 & 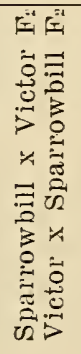 & 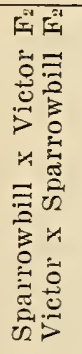 \\
\hline
\end{tabular}


the parental material grown in 1923 and 1924. All the plants of one parent grown the same year are placed in one frequency distribution.

The number of parent plants grown in 1923 was rather small, due to lack of seed. It will be noticed from this table that the average length of grain of both parents was more than one millimeter shorter in 1924 than in 1923. There was a greater difference between the two parents in 1924 than in 1923 as the grain length of Sparrowbill was reduced more by environmental conditions than was Victor.

The few $F_{1}$ plants grown were intermediate in grain length (see illustration on page 6), although they are nearer the Victor than the Sparrowbill. The coefficients of variability of the $\mathrm{F}_{2}$ generation were about twice as large as for the parents. It will be noted that in no case was there transgressive segregation in $F_{2}$. In 1923, plants with grains as short as Sparrowbill and others with grain as long as Victor were obtained (see illustration on page 15). In 1924, the upper limit was reached, while no plants were found with grains shorter than twelve millimeters, which is two millimeters longer than the shortest Sparrowbill grains obtained that year. As was the case with the parents, the mean length of grain of the $F_{2}$ plants was shorter in 1924 than in 1923.

To obtain a more accurate indication as to the behavior of the hybrids for length of grain, seventy-five families of Sparrowbill crossed with Victor, and seventy-five families of the reciprocal, were continued in $F_{3}$. The number of plants in each family varied from twenty to forty-five, with the exception of four families which contained less than twenty plants. It is realized that a larger number of plants per family would have been more desirable, but this would have necessitated growing fewer families, since the time required to measure the grains from a plant limited the amount of material wwhich could be studied.

Detailed data consisting of the mean and the coefficient of variability of each $\mathrm{F}_{3}$ family grown in 1924 as well as the mean length of grain of each $\mathrm{F}_{2}$ parent plant are given in Tables 29 and 30 of the appendix.

To determine the extent to which grain length in $F_{2}$ was a result of inheritance, a correlation coefficient was calculated for average grain length of the $F_{2}$ plants in relation to their $F_{3}$ breeding behaviour (see Table 5). A correlation coefficient of $+0.705 \pm 0.28$ was obtained, which indicates that the character studied is an unusually stable one for a size character. 


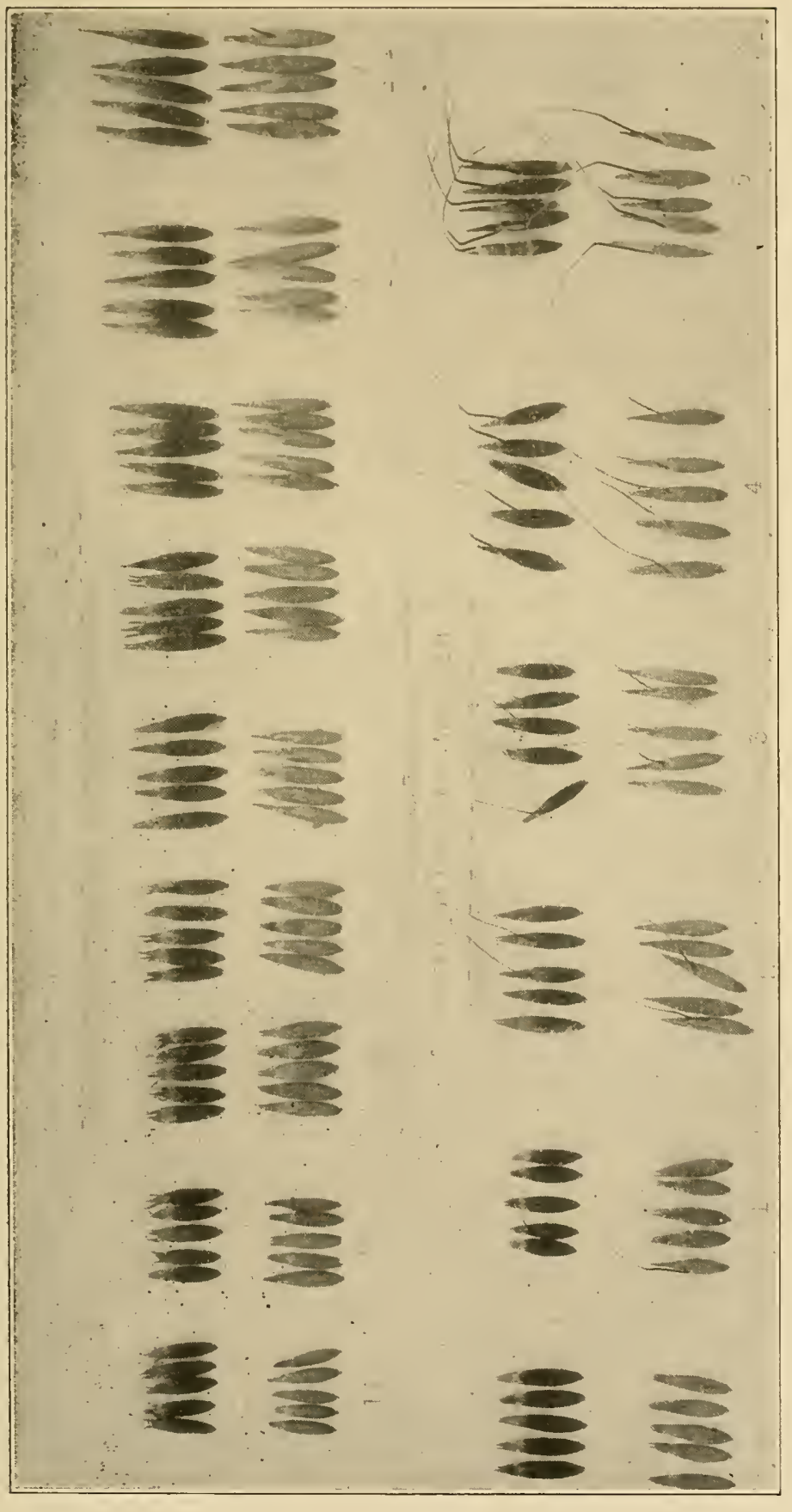

$\begin{array}{ll}\frac{1}{2} & \frac{1}{0} \\ 0 & \frac{0}{3} \\ \frac{2}{3} & \frac{1}{3} \\ Z & Z\end{array}$

$\frac{i}{\frac{\pi}{5}} \quad \frac{\dot{0}}{\pi}$

$\frac{0}{3} \stackrel{ \pm}{3}$

$\begin{array}{ll}3 & 3 \\ 0 & 0\end{array}$

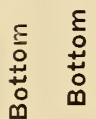

is is

जे $>0$

도 $\frac{1}{0}$ 뚱

$\frac{\pi}{m}=m$

क

$3^{\infty} 3_{0}^{\infty}$

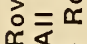

$x<$ 。 응 $>1$

1 I

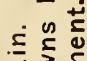

ส

它《

पै

ᄃ ญ

넝

도오

泣

용ㅇㅇ

엉용

䒕至元

त

잉 - 둥

ᄃ $\frac{5}{\pi} \varepsilon^{\frac{2}{2}}$

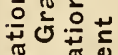

용

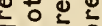

던ㄷㅇㅇ

のலゅ品

$\begin{array}{ll}\dddot{1} & \vdots \\ 0 & \vdots \\ 2 & 0 \\ 2 & 0\end{array}$ 
TABLE 5.-Relation of Length of Grain on $F_{2}$ Plants and Mean Length of Grain of $\mathrm{F}_{3}$ Family.

\begin{tabular}{|c|c|c|c|c|c|c|c|c|c|c|c|c|}
\hline \multirow{2}{*}{$\begin{array}{l}\text { Length of } \\
F_{2} \text { Grain }\end{array}$} & \multicolumn{11}{|c|}{ Classes for Mean Length of Grain in $F_{3}$ Family in Millimeters } & \multirow{2}{*}{ Total } \\
\hline & 11.5 & 12.0 & 12.5 & 13.0 & 13.5 & 14.0 & 14.5 & 15.0 & 15.5 & 16.0 & 16.5 & \\
\hline 13.0 & \multirow[t]{12}{*}{1} & \multirow{12}{*}{$\begin{array}{l}1 \\
1 \\
1\end{array}$} & \multirow{12}{*}{$\begin{array}{l}1 \\
4 \\
2 \\
6 \\
2\end{array}$} & \multirow{12}{*}{$\begin{array}{l}2 \\
2\end{array}$} & \multirow{3}{*}{1} & \multirow{3}{*}{1} & \multirow[b]{5}{*}{2} & \multirow[b]{5}{*}{2} & \multirow[b]{7}{*}{1} & \multirow{9}{*}{1} & & \multirow{12}{*}{$\begin{array}{r}2 \\
6 \\
7 \\
7 \\
29 \\
22 \\
28 \\
21 \\
16 \\
8 \\
2 \\
2\end{array}$} \\
\hline 13.5 & & & & & & & & & & & & \\
\hline 14.0 & & & & & & & & & & & & \\
\hline 14.5 & & & & & 4 & 1 & & & & & & \\
\hline 15.0 & & & & & 10 & 3 & & & & & & \\
\hline 15.5 & & & & & 8 & 8 & & & & & & \\
\hline 16.0 & & & & & 9 & 5 & 8 & 3 & & & & \\
\hline 16.5 & & & & & 2 & 4 & 11 & 1 & 1 & & & \\
\hline 17.0 & & & & & & 5 & 5 & 2 & 3 & & & \\
\hline 17.5 & & & & & 1 & & 4 & 1 & 2 & & & \\
\hline 18.0 & & & & & & & & 1 & & & 1 & \\
\hline 18.5 & & & & & & & 1 & & 1 & & & \\
\hline Total & 1 & 3 & 15 & 17 & 35 & 27 & $\overline{31}$ & 10 & 8 & 2 & 1 & 150 \\
\hline
\end{tabular}

$\mathrm{r}=+0.705 \pm 0.028$

The coefficient of variability may be used as an indication as to whether an $\mathrm{F}_{3}$ family is segregating for grain length, the variability of the parental material being used as a criterion of the homozygous condition. The mean grain length of each family is given in Table 6 with respect to the coefficient of variability for the family. The coefficients of variability were grouped into classes of 1.0 per cent, while the classes for the length of grain were 0.50 millimeters. The parents and $\mathrm{F}_{2}$ data are presented for comparison. In the Victor parent in 1924 the coefficient of variability of the means obtained in different plots varied from 1.5 per cent to 4.5 per cent, while, in the Sparrowbill for the same year, the range was from 3.5 per cent to 6.5 per cent. On this basis any $F_{3}$ family with a coefficient of variability of 4.5 per cent or less was considered as probably homozygous for length of grain. For the shorter grained families those with a coefficient of 6.5 per cent or less are possibly homozygous. It is apparent that about two families may be considered as homozygous for short grain and about four for long grain. Between these two extremes there are families which are apparently homozygous for grain of intermediate lengths.

It is evident that the type of segregation displayed here is typical for size inheritance, and may be explained on a multiple factor basis. The following explanation is suggested on a three factor basis. The difference in grain length between the parents in 1924 was 4.9 millirieters. Assuming that each of the three factors has an equal influence on grain length, or 1.6 millimeters increase when homozygous there should be in $F_{3}$, on a basis of sixty-four families, one family breeding true for a length of 16.3 millimeters, three families breed- 
TABLE 6.-Average Length of Grain in Relation to the Coefficient of Variability of $\mathrm{F}_{2}$ and $\mathrm{F}_{3}$ Families of a Cross Victor with Sparrowbill, and Reciprocal. Grain Lengths of Parents are Included for Comparison.

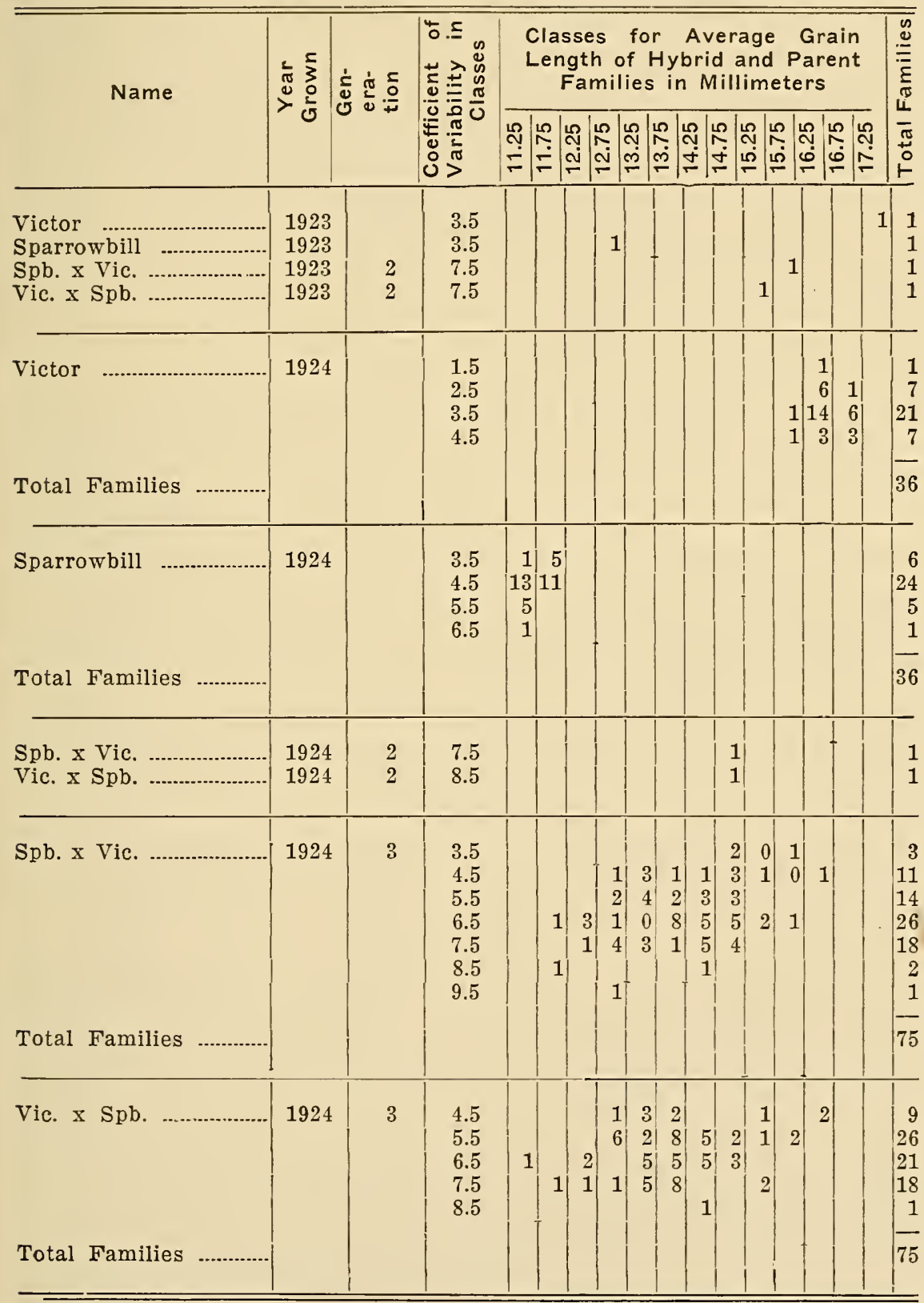


ing true for a length of 14.7 millimeters, three families breeding true for a length of 13.1 millimeters, and one family breeding true for grain 11.5 millimeters long. In Table 7 these calculated figures are compared with the observed $\mathrm{F}_{3}$ data.

TABLE 7.-Comparison of Observed and Calculated Number of $F_{8}$ Families Homozygous for Various Grain Lengths.

\begin{tabular}{|c|c|c|c|c|c|}
\hline \multirow{2}{*}{$\begin{array}{l}\text { Kind of } \\
\text { Ratio }\end{array}$} & \multicolumn{4}{|c|}{$\begin{array}{l}\text { Families Homozygous for Grain } \\
\text { Length in Millimeters of }\end{array}$} & \multirow[t]{2}{*}{ Total } \\
\hline & 16.3 & 14.7 & 13.1 & 11.5 & \\
\hline Calculated .... & \multirow{2}{*}{$\begin{array}{l}2.4 \\
2.0\end{array}$} & \multirow{2}{*}{$\begin{array}{l}7.2 \\
5.0\end{array}$} & \multirow{2}{*}{$\begin{array}{l}7.2 \\
8.0\end{array}$} & \multirow{2}{*}{$\begin{array}{l}2.4 \\
4.0\end{array}$} & \multirow{2}{*}{$\begin{array}{l}19 \\
19\end{array}$} \\
\hline Observed & & & & & \\
\hline
\end{tabular}

To definitely establish limits between families homozygous and heterozygous, for different lengths of grain, is only a rough approximation, the real test being a more extensive breeding study or the actual locating of the factors for length of grain in definite linkage groups. It is easily demonstrated that a line segregating for one factor pair might give differences in length so small that they could not be distinguished from environmental fluctuations.

In the preceeding paragraph it is shown that apparently each factor pair for grain length when homozygous gives an increase in length of 1.6 millimeters. If each of the three factors had half the influence in the heterozygous condition as when homozygous the $F_{1}$ plants would have grains which averaged about 13.9 millimeters in length. The $F_{1}$ plants grown in 1924, however, had grains which averaged 15.3 millimeters in length indicating that each factor in the heterozygous condition increases the length of grain 1.2 millimeters.

\section{Color of Grain}

In the cross under consideration, the Victor parent has black grain and Sparrowbill parent white. All the $F_{1}$ plants produced black grain, possibly not as intense in color as Victor. The segregation for color in $\mathrm{F}_{2}$ for all families grown is presented in Table 8.

In all cases the observed numbers are very close to the calculated for a $3: 1$ ratio. For the totals the deviation divided by the probable error is 1.5 , indicating that black and white color are probably controlled by a single factor difference.

To test the accuracy of the $\mathrm{F}_{2}$ classification for grain color the breeding behavior of the $\mathrm{F}_{3}$ families was studied in relation to the classification for grain color of the parent $F_{2}$ plant. The detailed 
breeding behavior of the various families are presented in Tables 31 and 32 of the appendix, and are summarized in Table 9. Two plants were classed as black in $F_{2}$ when, actually, they were white. This is easily accounted for, since color does not develop exceptionally well under the moist growing conditions of West Virginia. The results obtained, however, prove that, in general, the $\mathrm{F}_{2}$ classification for grain color was approximately correct.

TABLE 8.-Inheritance of Grain Color in $\mathrm{F}_{2}$ Progenies of the Cross Sparrowbill with Victor and Reciprocal.

\begin{tabular}{|c|c|c|c|c|}
\hline \multirow[t]{2}{*}{ Cross } & \multirow[t]{2}{*}{ Year } & \multicolumn{2}{|c|}{$\begin{array}{llr}\text { Total } & \text { Number of } \\
\text { Plants } & \begin{array}{l}\text { in } F_{2} \\
\text { Grain with }\end{array} \\
\end{array}$} & \multirow[t]{2}{*}{ Total } \\
\hline & & Black & White & \\
\hline 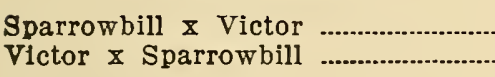 & $\begin{array}{l}1923 \\
1923\end{array}$ & $\begin{array}{l}116 \\
332\end{array}$ & $\begin{array}{r}37 \\
100\end{array}$ & $\begin{array}{l}153 \\
432\end{array}$ \\
\hline $\begin{array}{l}\text { Sparrowbill x Victor } \\
\text { Victor x Sparrowbill }\end{array}$ & $\begin{array}{l}1924 \\
1924\end{array}$ & $\begin{array}{l}146 \\
169\end{array}$ & $\begin{array}{l}43 \\
55\end{array}$ & $\begin{array}{l}189 \\
224\end{array}$ \\
\hline Total observed & & 763 & 235 & 998 \\
\hline Calculated $3: 1$ & & 748.5 & 249.5 & 998 \\
\hline
\end{tabular}

Deviation $=14.50$.

P. E. $=9.23$.

Dev./P. E. $=1.5$.

TABLE 9.-Summary of Breeding Behavior of $\mathrm{F}_{3}$ Families for Color of Grain.

\begin{tabular}{|c|c|c|c|c|c|}
\hline \multirow{2}{*}{ Name } & \multirow{2}{*}{$\begin{array}{c}\text { F, Color } \\
\text { Descrip- } \\
\text { tion }\end{array}$} & \multicolumn{3}{|c|}{ Fs Breeding Behavior } & \multirow{2}{*}{ Total } \\
\hline & & Black & $\begin{array}{l}\text { Segre- } \\
\text { gating }\end{array}$ & White & \\
\hline \multirow{2}{*}{$\begin{array}{l}\text { Sparrowbill x Victor } \\
\text { and Reclprocal }\end{array}$} & Black & \multirow[t]{2}{*}{35} & \multirow[t]{2}{*}{73} & 2 & 110 \\
\hline & White & & & 40 & 40 \\
\hline Total & & 35 & 73 & 42 & 150 \\
\hline
\end{tabular}

$\mathrm{X}^{2}=$ Less than 1. $\mathrm{P}=$ Very good.

The data for the segregation for black and white grain color agree in general with the results obtained by Wilson (1907), Gaines (1917), Zinn and Surface (1917), Love and Craig (1918), Wakabayashi (1921) and Nilsson-Ehle (1909). 


\section{Panicle Type}

As pointed out in the description of the parents, Sparrowbill has a side or "horse mane" type of panicle, while Victor has an open or branched panicle. The $F_{1}$ of the cross between these two varieties was open-panicled. In the $F_{2}$ generation the ratio of open-panicled plants to side-panicled was close to a 15:1 calculated on the basis of a two factor difference, the factors for open panicle being duplicate (see Table 10).

TABLE 10.-Segregation for Panicle Type in $\mathrm{F}_{2}$ Plants of the Cross Sparrowbill with Victor and Reciprocal.

\begin{tabular}{|c|c|c|c|c|}
\hline \multirow[t]{2}{*}{ Cross } & \multirow[t]{2}{*}{ Year } & \multicolumn{2}{|c|}{$\begin{array}{l}\text { Total Number of } \\
\text { Plants in } F_{2} \text { with } \\
\text { Panicles }\end{array}$} & \multirow[t]{2}{*}{ Total } \\
\hline & & Open & Side & \\
\hline $\begin{array}{l}\text { Sparrowbill x Victor } \\
\text { Victor } x \text { Sparrowbill }\end{array}$ & $\begin{array}{l}1923 \\
1923\end{array}$ & $\begin{array}{l}143 \\
403\end{array}$ & $\begin{array}{l}10 \\
29\end{array}$ & $\begin{array}{l}153 \\
432\end{array}$ \\
\hline $\begin{array}{l}\text { Sparrowbill } x \text { Victor } \\
\text { Victor } x \text { Sparrowbill }\end{array}$ & $\begin{array}{l}1924 \\
1924\end{array}$ & $\begin{array}{l}174 \\
210\end{array}$ & $\begin{array}{l}15 \\
14\end{array}$ & $\begin{array}{l}189 \\
224\end{array}$ \\
\hline $\begin{array}{l}\text { Total observed } \\
\text { Calculated } 15: 1\end{array}$ & & $\begin{array}{l}930 \\
936\end{array}$ & $\begin{array}{l}68 \\
62\end{array}$ & $\begin{array}{l}998 \\
998\end{array}$ \\
\hline
\end{tabular}

Deviation $=6$

P. E. $=5.16$.

Dev./P. E. = 1.1

In selecting the $F_{2}$ plants to continue in $F_{3}$ more plants classed as side in $\mathrm{F}_{2}$ were continued than probably would have been had the selection been entirely at random. For complete data on the $\mathrm{F}_{3}$ families for panicle type see Tables 31 and 32 in the appendix. These data are summarized in Table 11.

TABLE 11.-Breeding Behavior of the $F_{3}$ Families for Panicle Type.

\begin{tabular}{c|c|c|c|c}
\hline \hline \multirow{2}{*}{$\begin{array}{c}F_{2} \text { Panicle } \\
\text { Description }\end{array}$} & \multicolumn{3}{|c|}{ F $_{3}$ Breeding Behavior } & Total \\
\cline { 2 - 5 } & Open & Segregating & Side & \\
\hline Open ............................. & 65 & 68 & 10 & 133 \\
\hline Total & & 7 & 10 & 150 \\
\hline
\end{tabular}


In all cases $F_{2}$ plants classed as open bred true for open panicle or segregated in $F_{3}$. In the case of plants classed as side in $F_{2}$, seven segregated; showing that, in reality, they should have been classed as open. If the classification of the $F_{2}$ material grown in 1923 is corrected on a basis of the breeding behavior of the $F_{3}$ the observed ratio would be $562: 23$. The calculated is $548: 37$, giving a deviation of 14, which is 3.5 times the probable error, giving odds of about $54: 1$ against a deviation as great as the one observed being due to chance alone.

The $\mathrm{F}_{3}$ lines which were grown may be used to determine whether the breeding behavior for panicle type could be explained on the two factor hypothesis. Had the same per cent of $F_{2}$ plants classed as sicle panicle been continued in $\mathrm{F}_{3}$, as were $\mathrm{F}_{2}$ plants classed as open, ten would have been grown instead of seventeen. According to the breeding behavior of the $17 \mathrm{~F}_{2}$ side plants continued, 41 per cent, or seven, segregated. On this same basis on the average four out of ten plants would be expected to segregate in $\mathrm{F}_{3}$. Combining these data with the breeding results of the open panicle $F_{2}$ plants, $i_{t}$ is found that sixty-five bred true for open panicle, seventy-two segregated, and six bred true for side panicle. The calculated breeding behavior on the two factor basis is $63: 71: 9$. Comparing these two results by the $\mathrm{X}^{2}$ method gives a $\mathrm{P}$. of .5880 . The data obtained in this study indicate that the parents differed in two main factors for panicle type, one or both factors in the dominant condition giving open panicles. These results agree with those obtained by NilssonEhle (1909), while Garber (1922) found that in Minota or Victory crossed with White Russian the results were best explained on a single factor difference. Wakabayashi (1921) states that in a cross Red Rust Proof with Black Tartarian, the inheritance of shape of panicle, if Mendelian, is probably best explained on a basis of multiple factors. Variable results, not explainable on a single factor basis, are reported by Gaines (1917) in crosses of side-panicled with openpanicled types.

\section{Degree of Awn Development}

The variety Victor carries a rather heavy, black tivisted, geniculate awn on the primary grain, while the Sparrowbill variety is awnless in most cases (see illustration on page 6). Occasionally, however, one or two primary grains in a panicle of Sparrowbill will be awned, the strength of the awn varying from very weak to a rather short, black twisted, but rarely geniculate awn. In no case was the awn of Sparrowbill nearly as long or as heavy as on Victor. In 
taking the awn notes an arbitrary scale of numbers from " 0 " to " 5 " was used. The total absence of awns was denoted by " 0 ", while " 1 " indicated the presence of one or two awns in the panicle. More than two grains with awns were indicated by " 2 ", while " 3 " represented a more or less intermediate condition between the two parents as to number and strength of awn. A plant classed as "4" had practically all of the primary grains awned, but the awns were not all geniculate, while " 5 " indicated the presence of a black, twisted, and geniculate awn on every primary grain in the panicle. (See illustration on page 15).

Unfortunately but few data were taken to determine the variability of the two parents for awns (see Table 12). A study of the data taken, however, indicates that both parents vary with respect to awns, the Sparrowbill giving all " 0 " and " 1 " types, while the Victor gives mostly "5," with a few "4" types.

The awns of the $F_{1}$ plants of this cross were of an intermediate type, not quite as heavy as the Victor parent, and were classed as " 3 " or "4". A summary of awn development of the $F_{2}$ material grown in 1923 and 1914 is given in Table 12.

TABLE 12.-Behavior of Awn Development in $F_{2}$ and Parent Plants Grown in 1923 and 1924.

\begin{tabular}{|c|c|c|c|c|c|c|c|c|}
\hline \multirow[t]{2}{*}{ Name } & \multirow[t]{2}{*}{ Year } & \multicolumn{6}{|c|}{$\begin{array}{l}\text { Number of Plants in } F_{2} \\
\text { With Awns Classed as }\end{array}$} & \multirow[t]{2}{*}{ Tota } \\
\hline & & 0 & 1 & 2 & 3 & 4 & 5 & \\
\hline Victor & 1923 & & & & & 5 & 35 & 40 \\
\hline Sparrowbill ......... & 1923 & 35 & 19 & & & & & 64 \\
\hline Sparrowbill $\mathrm{x}$ Victor......... & 1923 & & 15 & 25 & 55 & 27 & 31 & 153 \\
\hline Victor x Sparrowbill.... & 1923 & 9 & 36 & 68 & 129 & 105 & 85 & 432 \\
\hline Sparrowbill $\mathrm{x}$ Victor........ & 1924 & 2 & 15 & 11 & 24 & 75 & 62 & 189 \\
\hline Victor $\mathrm{x}$ Sparrowbill....... & 1924 & 3 & 15 & 22 & 41 & 75 & 68 & 224 \\
\hline Total for Hybrids.. & & 14 & 81 & 126 & 249 & 282 & 246 & 998 \\
\hline
\end{tabular}

The detailed breeding behavior for awns of the hundred and fifty families grown in $F_{3}$ is given in Tables 31 and 32 of the appendix. The results are summarized in Table 13.

In the classification of the $F_{3}$ families for awns, the awnless class includes those lines which were as awnless as Sparrowbill. In the "awnless dominant" class most of the plants were awnless, although a few plants were present with stronger awns. The "like $\mathrm{F}_{2}$ " class showed segregation similar to that of $\mathrm{F}_{2}$ The "awns dominant" class consisted of those lines in which awned plants predominated; while "awned" group consisted of such lines as bred as truly awned as the Victor parent. 
TABLE 13.-Summary of Breeding Behavior of $F_{3}$ Families for Awns.

\begin{tabular}{|c|c|c|c|c|c|c|}
\hline \multirow{2}{*}{$\begin{array}{c}F_{2} \text { Awn } \\
\text { Class }\end{array}$} & \multicolumn{5}{|c|}{ Classification of $F_{3}$ Families for Awns } & \multirow[b]{2}{*}{ Total } \\
\hline & Awnless & $\begin{array}{l}\text { Awnless } \\
\text { Dominant }\end{array}$ & Like $F_{2}$ & $\begin{array}{c}\text { Awns } \\
\text { Dominant }\end{array}$ & Awned & \\
\hline $\begin{array}{l}0 \\
1 \\
2 \\
3 \\
4 \\
5\end{array}$ & $\begin{array}{l}1 \\
1\end{array}$ & $\begin{array}{l}3 \\
1 \\
2\end{array}$ & $\begin{array}{c}13 \\
22 \\
34 \\
8 \\
3\end{array}$ & $\begin{array}{r}2 \\
16 \\
23 \\
11\end{array}$ & $\begin{array}{l}1 \\
4 \\
5\end{array}$ & $\begin{array}{r}1 \\
17 \\
25 \\
53 \\
35 \\
19\end{array}$ \\
\hline Total & 2 & 6 & 80 & 52 & 10 & 150 \\
\hline
\end{tabular}

The data obtained indicate a close relation between the $\mathrm{F}_{2}$ classification and the breeding behavior in $F_{3}$. The only plant classed as " 0 " in $\mathrm{F}_{2}$ that was continued bred awnless. The " 1 " class gave a predominating number of families segregating like $\mathrm{F}_{2}$. The "2" and " 3 " classes gave a more or less segregating type of $F_{3}$ reaction, while " 4 " and " 5 " classes tended to give mostly awns dominant and awned $\mathrm{F}_{3}$ lines.

The expression of awns is quite variable, and apparently considered influenced by environment. Because of the fact that no extensive notes are available regarding the variation of awns on the parents from one part of the field to another, a careful analysis of the hybrids is impossible.

Previous workers, studying the inheritance of awns have reported varying results. Norton (1907), by crossing awned and awnless forms obtained a ratio in $\mathrm{F}_{2}$ of 1 awned: 2 hybrid type: 1 awnless. In crosses between Avena fatua and Kherson, Surface (1916) found that the factors for awns behaved as a simple Mendelian factor pair, giving 3 awned to 1 not fully awned. In $F_{3}$, however, the awnless plants failed to breed true in all cases; in fact, only five lines in twenty gave all awnless forms. Surface concludes that the character is very variable. Love and Frazer (1917) in a cross Burt (weak awned) with 60 Day (awnless) obtained a ratio in $F_{2}$ of 1 awnless: 2 intermediate: 1 awned. The awned plants bred true, the intermediate plants again segregated, while some of the awnless plants bred true and others were heterozygous. They considered that awning was influenced by environment. Love and Craig (1918), in a cross 60 Day with Avena fatua found fully awned recessive to weak awn. Fraser (1919) in crosses between strong and weak awned parents found the fully awned type recessive. Awnless $F_{2}$ plants failed to breed true in all cases. Some of these variable results were 
explained by an inhibiting factor linked with the factor for yellow color in 60 Day. Fraser also states that awns are influenced by environment.

The present study probably deals with material behaving in much the same way as the weak awn condition reported by Love and Fraser, Love and Craig, and Fraser. In the work here, very few families were obtained which bred true for awnlessness, and relatively few bred true for strong awns, although there were more homozygous awned than awnless lines. It is hardly possible to explain the segregation on a single factor difference.

\section{CORRELATED INHERITANCE OF CHARACTERS}

A further object of this study was to determine any possible genetic linkages, if such occurred.

\section{Relation of Length of Grain and Color of Grain}

Data regarding the relation between grain length and color of grain in the $\mathrm{F}_{2}$ generation of the cross Sparrowbill with Victor and reciprocal grown in 1923 and 1924 are presented in Table 14. In Table 15 are given data on the length of grain of the various $F_{3}$ families, homozygous for white or black color or segregating.

TABLE 14.-Relation of Length and Color of Grain in $F_{2}$ Progenies of the Cross Sparrowbill with Victor and Reciprocal.

\begin{tabular}{|c|c|c|c|c|c|c|c|c|c|c|c|c|c|}
\hline \multirow[t]{2}{*}{ Year } & \multirow[t]{2}{*}{$\begin{array}{l}\text { Color } \\
\text { of } \\
\text { Grain }\end{array}$} & \multicolumn{8}{|c|}{$\begin{array}{c}\text { Frequency Distribution for } \\
\text { Grain Length in Milli- } \\
\text { meters }\end{array}$} & \multirow[t]{2}{*}{ Total } & \multirow[t]{2}{*}{ Mean } & \multirow[t]{2}{*}{ Difference } & \multirow{2}{*}{ 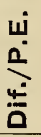 } \\
\hline & & 12 & 13 & $|14|$ & 15 & 16 & 171 & 18 & 91 & & & & \\
\hline 1923 & Black & 4 & 16 & 69 & 122 & 145 & $77^{\prime}$ & 12 & 3 & 448 & $15.52 \pm$ & $0.12 \pm 0.07$ & 1.7 \\
\hline 1923 & White & 1 & 6 & 19 & 42 & 50 & 18 & 1 & & 137 & $15.40=$ & & \\
\hline 1924 & Black & 15 & 72 & 112 & 70 & 39 & 6 & & & 314 & $14.20=$ & $0.12 \pm 0.09$ & 1.3 \\
\hline 1924 & White & $4 \mid$ & 19 & | $34 \mid$ & $27 \mid$ & 11 | & $3 \mid$ & & & 98 & $14.32 \pm 0.09$ & & \\
\hline
\end{tabular}

From the date of the $F_{2}$ generation it is seen that there was no difference in grain length, between the black and the white plants. This same condition was found in the $F_{3}$ generation since there was no significant difference in length of grain between families homozygous for white grain and families homozygous for black grain. There was no significant difference in length of grain between the families segregating for color and either the black or white families. It seems safe to assume that there is no linkage between factors for length of grain and color or grain. 
TABLE 15.-Breeding Behavior of $F_{3}$ Lines of the Cross Sparrowwith Victor and Reciprocal for Grain Length and Grain Color, Grown in 1924.

\begin{tabular}{|c|c|c|c|c|c|c|c|c|c|c|c|c|c|c|c|}
\hline \multirow{2}{*}{$\begin{array}{l}\text { Color } \\
\text { Behav- } \\
\text { ior of } \\
\text { Line }\end{array}$} & \multicolumn{11}{|c|}{$\begin{array}{c}\text { Mean Length of Grain in } F_{3} \text { Families } \\
\text { in Millimeters }\end{array}$} & \multirow{2}{*}{ Total } & \multirow{2}{*}{ Mean } & \multirow{2}{*}{ Difference } & \multirow{2}{*}{$\sum_{0}^{u}$} \\
\hline & $\stackrel{n}{=}$ & 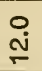 & 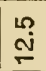 & $\stackrel{\circ}{\stackrel{\rho}{\sim}}$ & $\mid$ & $\stackrel{\circ}{\dot{+}}$ & $\stackrel{\operatorname{Ln}}{\leftarrow}$ & $\stackrel{0}{\circ}$ & $\stackrel{\operatorname{Ln}}{\stackrel{2}{2}}$ & $\stackrel{0}{0}$ & \begin{tabular}{|l|}
$\underline{10}$ \\
6 \\
0
\end{tabular} & & & & \\
\hline Black & & 1 & 3 & 4 & 5 & 3 & 10 & 5 & 3 & 1 & & 35 & $14.10 \pm 0.11$ & $\begin{array}{c}\text { Black \&White } \\
+0.23 \pm 0.14\end{array}$ & 1.6 \\
\hline Seg. & 1 & 1 & 9 & 8 & 20 & 13 & 13 & 4 & 4 & & & 73 & $13.73 \pm 0.07$ & $\begin{array}{l}\text { illack \& Seg. } \\
+0.37 \pm 0.13\end{array}$ & 2.8 \\
\hline White & & 1 & 3 & 5 & 10 & 11 & 8 & 1 & 1 & 1 & 1 & 42 & $13.87 \pm 0.09$ & $\begin{array}{l}\text { Seg \& White } \\
+0.14 \pm 0.11\end{array}$ & 1.3 \\
\hline
\end{tabular}

Relation of Length of Grain and Panicle Type

The data on the relation of length of grain and panicle type in the $\mathrm{F}_{2}$ families grown in 1923 and 1924 are presented in Table 16, while the $\mathrm{F}_{3}$ breeding behavior for these two characters is given in Table 17. In both years the open panicled plants had the longer grain.

TABLE 16.--Relation of Panicle Type and Length of Grain in $\mathbf{F}_{\mathbf{2}}$ Progenies of the Cross Sparrowbill with Victor and Reciprocal.

\begin{tabular}{|c|c|c|c|c|c|c|c|c|c|c|c|}
\hline \multirow[t]{2}{*}{$\frac{2}{8}$} & \multirow[t]{2}{*}{$\frac{\frac{0}{0}}{\frac{0}{c}} \frac{0}{\pi}$} & \multicolumn{5}{|c|}{$\begin{array}{c}\text { Frequency Distri- } \\
\text { tion for Grain } \\
\text { Length in Milli- } \\
\text { meters }\end{array}$} & \multirow{2}{*}{$\mid \begin{array}{l}\bar{\pi} \\
\stackrel{2}{0} \\
\stackrel{1}{-1}\end{array}$} & \multirow[t]{2}{*}{ Mean } & \multirow[t]{2}{*}{ Difference } & \multirow[t]{2}{*}{$\underbrace{\frac{u}{0}}_{\frac{4}{0}}$} & \multirow[t]{2}{*}{ Odds } \\
\hline & & \begin{tabular}{|l|l|l|}
$12|13| 14 \mid$ \\
\end{tabular} & $\mid 15$ & 16 & $|17| 18$ & & & & & & \\
\hline 1923 & Open & \begin{tabular}{l|l|l|}
3 & 180
\end{tabular} & 151 & 187 & $91 \mid 1$ & & 546 & $15.54 \pm 0.03$ & $+0.69 \pm 0.14$ & 4.9 & $\overline{1051: 1}$ \\
\hline 1923 & Side & 24 & 13 & 8 & 4 & & 39 & $14.85 \pm 0.14$ & & & \\
\hline 1924 & Open & 15 81 134 & 96 & 48 & 9 & & 384 & $14.29 \pm 0.04$ & $+0.74 \pm 0.14$ & 5.8 & $1350: 1$ \\
\hline 1924 & Side & \begin{tabular}{l|l|l}
4 & 10 & 12
\end{tabular} & 1 & 2 & & & 29 & $13.55 \pm 0.13$ & & & \\
\hline
\end{tabular}

From these data it is seen that homozygous open panicle families had grain $1.27 \pm 0.14$ millimeters longer than homozygous side panicle families. This difference is significant in the light of its probable error. The segregating rows are intermediate in length of grain between the side and open families, although they are nearer the homozygous opens in grain length than they are to the sides. The data for the $F_{2}$ and $F_{3}$ generations agree in general, bringing out the fact that side panicle plants have grains shorter than openpanicled plants. 
TABLE 17.-Breeding Behavior of $\mathrm{F}_{3}$ Lines of the Cross Sparrowbill with Victor and Reciprocal Grown in 1924.

\begin{tabular}{|c|c|c|c|c|c|c|c|c|c|c|c|c|c|c|c|}
\hline \multirow{2}{*}{$\begin{array}{c}\text { Panicle } \\
\text { Behav- } \\
\text { lor of } \\
\text { Line }\end{array}$} & \multicolumn{11}{|c|}{$\begin{array}{c}\text { Mean Length of Grain in Fs Families } \\
\text { in Millimeters }\end{array}$} & \multirow[b]{2}{*}{ Total } & \multirow[b]{2}{*}{ Mean } & \multirow[b]{2}{*}{ Difference } & \multirow{2}{*}{$\sum_{\frac{1}{a}}^{4}$} \\
\hline & 足 & iọ & $|\stackrel{1}{\mathfrak{N}}|$ & $\left|\begin{array}{l}0 \\
\stackrel{m}{\sim}\end{array}\right|$ & $\stackrel{n}{2}$ & $\stackrel{0}{\dot{q}}$ & $\stackrel{\operatorname{Ln}}{+}$ & 옹 & Ln & $\stackrel{0}{0}$ & 电 & & & & \\
\hline Open & & & 3 & 3 & 16 & 14 & 19 & 4 & 5 & 1 & & 65 & $14.12 \pm 0.06$ & Open \& Side & 9.3 \\
\hline Seg. & & 3 & 9 & 11 & 16 & 13 & 12 & 6 & 3 & 1 & 1 & 75 & $13.84 \pm 0.07$ & $\begin{array}{l}\text { Open \& Seg. } \\
+0.28 \pm 0.09\end{array}$ & 3.1 \\
\hline Stde & 1 & & 3 & 3 & 3 & & & & & & & 10 & $12.85 \pm 0.13$ & $\begin{array}{l}\text { Seg. \& Side } \\
+0.99 \pm 0.15\end{array}$ & 6.6 \\
\hline
\end{tabular}

Since there are two independent factors concerned in the development of panicle type, the question arises as to whether there is a length factor linked with each factor for open panicle. Theoretically, half of the segregating $F_{3}$ families should give 15:1 ratios and half give $3: 1$ ratios for open versus side panicle. If length factors are linked with both panicle factors, those families segregating 15:1 should have longer grain than those segregating $3: 1$. The segregating families were classified, where possible, into two classes as to manner of segregation, and the mean length of grain determined. Thirty-five families segregating in an approximate $3: 1$ ratio gave a mean grain length of $13.64 \pm 0.06$ millimeters. While 24 families segregating in a $15: 1$ manner had a mean length of $14.18 \pm 0.07$ millimeters, a length equal to that of the homozygous open families. The difference in favor of the $15: 1$ families is $0.54 \pm 0.09$. The odds against a difference as great as the one shown being due to chance are extremely high. From these data it would seem that two factors for grain length are linked, one with each of the two factors for panicle type.

\section{Relation of Length of Grain and Awn Development}

The data on the relation of grain length and awns in the $F_{2}$ generations grown in 1923 and 1924 are presented in the form of correlation surfaces in Tables 18 and 19, while the breeding behavior of the $\mathrm{F}_{3}$ families for the relation of these characters is given in Table 20.

A study of the data presented in these tables leads to the assumption that in the $\mathrm{F}_{2}$ generation there was a correlation between strong awns and long grain, as shown by the correlation ratio, which was of about the same value for 1923 and 1924 . The awn classes 
in the $F_{3}$ data are the same as presented in Table 13. In this case, the value for $\eta$ is $0.469 \pm 0.043$, and the data in the table shows that this relation is positive; the awned lines tending to have the longer grains.

TABLE 18.-Length of Grain and Awn Development of $\mathrm{F}_{2}$ Generation of the Cross Sparrowbill with Victor and Reciprocal, Grown in 1923.

\begin{tabular}{|c|c|c|c|c|c|c|c|c|c|}
\hline \multirow{2}{*}{$\begin{array}{l}\text { Awns } \\
\text { on } F_{2} \\
\text { Plants }\end{array}$} & \multicolumn{8}{|c|}{ Length of Grain on $F_{2}$ Plants in Millimeters } & \multirow{2}{*}{$\begin{array}{l}\text { Total } \\
\text { Plants }\end{array}$} \\
\hline & 12 & 13 & 14 & 15 & 16 & 17 & 18 & 19 & \\
\hline$\overline{0}$ & & & 4 & 4 & & & 1 & & 9 \\
\hline 1 & 2 & 7 & 13 & 23 & 5 & 1 & & & 51 \\
\hline 2 & 1 & 8 & 15 & 29 & 30 & 9 & 1 & & 93 \\
\hline 3 & & 5 & 35 & 50 & 69 & 24 & 1 & & 184 \\
\hline 4 & 1 & 1 & 11 & 42 & 45 & 29 & 1 & 2 & 132 \\
\hline 5 & 1 & 1 & 10 & 16 & 46 & 32 & 9 & 1 & 116 \\
\hline Total & 5 & 22 & 88 & 164 & 185 & 95 & 13 & 3 & 585 \\
\hline
\end{tabular}

$$
\eta=0.358 \pm 0.24
$$

CABLE 19.-Length of Grain and Awn Development of $F_{2}$ Generation of the Cross Sparrowbill with Victor and Reciprocal, Grown in 1924.

\begin{tabular}{c|c|c|c|c|c|c|c|c|c|c}
\hline \hline \multirow{2}{*}{$\begin{array}{c}\text { Awns } \\
\text { on } \mathbf{F}_{\mathbf{2}}\end{array}$} & \multicolumn{7}{|c|}{ Length of Grain on F Plants in Millimeters } & $\begin{array}{c}\text { Total } \\
\text { Plants }\end{array}$ \\
\cline { 2 - 12 } Plants & 12 & 13 & 14 & 15 & 16 & 17 & 18 & 19 & \\
\hline 0 & & 2 & 2 & 1 & & & & & 5 \\
1 & 8 & 8 & 8 & 3 & 3 & & & & 30 \\
2 & 5 & 8 & 15 & 3 & 1 & 1 & & & 33 \\
3 & 3 & 14 & 23 & 17 & 8 & & & & 65 \\
4 & 3 & 44 & 61 & 28 & 12 & 2 & & & 150 \\
5 & & 15 & 37 & 45 & 26 & 6 & 0 & 1 & 130 \\
\hline Total & 19 & 91 & 146 & 97 & 50 & 9 & 0 & 1 & 413 \\
\hline \hline
\end{tabular}

'ABLE 20.-Breeding Behavior of $F_{3}$ Families of the Cross Sparrowbill with Victor and Reciprocal for Length of Grain and Awn Development.

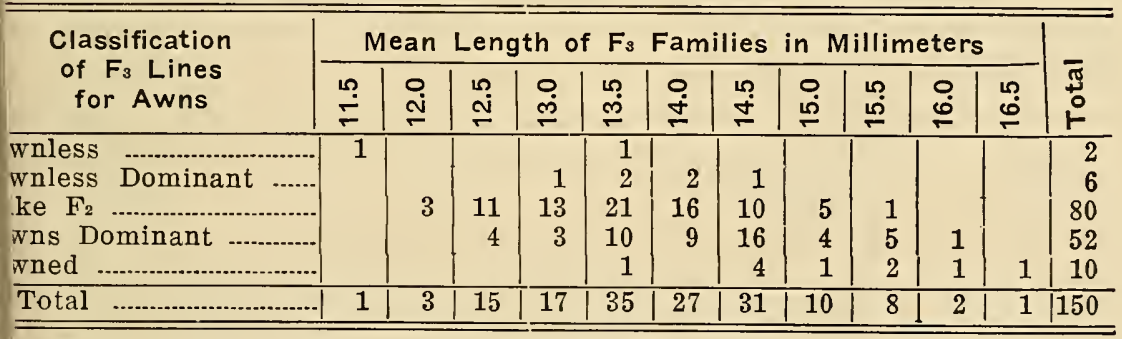

$\eta=0.469 \pm 0.43$ 
TABLE 21.-Relation of Grain Color and Panicle Type in $\mathrm{F}_{2}$ Progenies of the Cross Sparrowbill with Victor and Reciprocal.

\begin{tabular}{l|l|c|r|r|r|r|r|r}
\hline \hline Year & $\begin{array}{c}\text { Kind of } \\
\text { Ratio }\end{array}$ & $\begin{array}{c}\text { Black } \\
\text { Open }\end{array}$ & $\begin{array}{c}\text { White } \\
\text { Open }\end{array}$ & $\begin{array}{c}\text { Black } \\
\text { Side }\end{array}$ & $\begin{array}{c}\text { White } \\
\text { Side }\end{array}$ & Total & $\mathbf{X}^{2}$ & $\mathbf{P}$ \\
\hline 1923 & Obs'd & 420.00 & 126.00 & 28.00 & 11.00 & 585 & & \\
& Cal'd & 411.30 & 137.10 & 27.42 & 9.14 & 585 & 1.4734 & .6929 \\
& Obs'd & 295.00 & 89.00 & 20.00 & 9.00 & 413 & & \\
& Cal'd & 290.25 & 96.75 & 19.35 & 6.45 & 413 & 1.7285 & .6345 \\
Both & Obs'd & 715.00 & 215.00 & 48.00 & 20.00 & 998 & & \\
Years & Cal'd & 701.55 & 233.85 & 46.77 & 15.59 & 998 & 3.0569 & .3176 \\
\hline \hline
\end{tabular}

\section{Relation of Grain Color and Panicle Type}

The relation of color of grain and panicle type is given for the $F_{2}$ plants in Table 21 and for the $F_{3}$ families in Table 22 .

The data for $F_{2}$ indicate a very close fit to the calculated for a $45: 15: 3: 1$ ratio, assuming a two factor difference for panicle type and one for color. This tends to prove that the factor for color of grain and the factors for type of panicle are inherited independently.

The breeding behavior of the $F_{3}$ lines for color of grain and panicle type furnish more conclusive evidence that these factors are inherited independently, the observed ratio being very close to the calculated $(\mathrm{P}=0.9845)$.

TABLE 22.-Breeding Behavior for Color and Panicle Type of $F_{3}$ Families of the Cross Sparrowbill with Victor and Reciprocal, Grown in 1924.

\begin{tabular}{c|l|c|c}
\hline \hline Panicle class & \multicolumn{1}{|c|}{ Color Class } & $\begin{array}{c}\text { Observed } \\
\text { Numbers }\end{array}$ & $\begin{array}{c}\text { Calculated } \\
\text { Numbers }\end{array}$ \\
\hline Open & Black & 15 & 16.41 \\
Open & Segregating & 30 & 32.81 \\
& White & 20 & 16.41 \\
\hline Segregating & Black & 18 & 18.75 \\
Segregating & Segregating & 37 & 37.50 \\
Segregating & White & 20 & 18.75 \\
\hline Side & Black & 2 & 2.34 \\
Side & Segregating & 6 & 2.68 \\
Side & White & 2 & 2.34 \\
\hline Total & & 150 & 150 \\
\hline
\end{tabular}


Although an attempt was made to select at random the $F_{2}$ plants to continue in $\mathrm{F}_{3}$ it has been shown that too many side panicle plants. were continued for a random selection. In the $\mathrm{F}_{3}$ data presented here regarding the relation of panicle type and grain color no correction is attempted, and for this reason the value of $P$ is probably slightly too high.

\section{Relation of Grain Color and Awn Development}

Data for the relation between grain color and awns in the $F_{z}$ hybrids of the Sparrowbill with Victor cross are presented in Table 33 of the appendix. In addition to the actual numbers observed in each awn class, the percentage of individuals in each class is given. It will be seen that among the plants with white grains the percentage of awns in the " 0 ", " 1 ", and " 2 " classes is higher than among plants with black grain, while in the " 3 " and " 4 " awn classes there is not so much difference, although the blacks are usually in excess in the " 4 " class. In the "5" awn class the whites fall off quite sharply. This would possibly indicate that the factors for black color and for awn development are linked.

To determine if the white and black grained plants did actually behave differently for awns, $\mathrm{X}^{2}$ was computed on the percentage figures, using the black plants as the calculated and the whites as observed. It will be seen that for the 1923 data $P$ is very low, while for 1924 the fit is very good. Combining the two years results $\mathrm{P}=$ .2894 , or, more often than once out of four trials a worse result than the one observed would be expected due to chance. This fit is not at all bad, and the results indicate that if there is linkage it is not close.

The breeding behavior of the hundred and fifty $F_{3}$ families for grain color and awns is presented in Table 23. There is a marked tendency for the families homozygous for black grain to be awned, or partly awned, as in no case was there a homozygous black grained line breeding true for awnlessness. In the homozygous white lines, however, three families in forty-two were homozygous for awns, ten had awns dominant, although only two had awnlessness dominant and none were awnless. This again indicates that, for some reason, too few lines were found breeding true for awnlessness. If there is linkage between the factor for color and a factor for awns, which is doubtful, it must be considered as very loose. 
TABLE 23.-Breeding Behavior for Color of Grain and Awns in $F_{3}$ Families of the Cross Sparrowbill with Victor and Reciprocal, Grown in 1924.

\begin{tabular}{|c|c|c|c|c|c|c|}
\hline \multirow{2}{*}{$\begin{array}{c}\text { Color } \\
\text { of } \\
\text { Grain }\end{array}$} & \multicolumn{5}{|c|}{ Behavior for Awns } & \multirow[b]{2}{*}{ Total } \\
\hline & Awned & $\begin{array}{c}\text { Awns } \\
\text { Dominant }\end{array}$ & Like $F_{2}$ & $\mid \begin{array}{c}\text { Awnless } \\
\text { Dominant }\end{array}$ & Awnless & \\
\hline$\overline{\text { Black ........... }}$ & 3 & 16 & 16 & & & 35 \\
\hline Seg. & 4 & 26 & 37 & 4 & 2 & 73 \\
\hline White & 3 & 10 & 27 & 2 & & 42 \\
\hline Total & 10 & 52 & 80 & 6 & 2 & 150 \\
\hline
\end{tabular}

\section{Relation of Panicle Type and Awn Development}

There seems to be a close linkage between open panicles and awns, as the percentage of individuals with stronger awns is much higher in the open panicle plants than in the side types (see Table 34 of the appendix). Considering both $\mathrm{F}_{2}$ families grown, 79 per cent of the open panicle plants had awns of class " 3 " or stronger, while only 57 per cent of the side plants were classed in this group. Of the open panicle plants 20 per cent had " 0 ", " 1 ", or " 2 " awns, while 43 per cent of the side panicle plants were classed with awns of class " 2 " or less. $\mathrm{X}^{2}$ was computed for these data, using the open panicle group as the calculated and the side types as the observed. In all cases $P$ is very low, indicating that there is little probability that the deviations observed are due to chance.

A study of the $F_{3}$ lines for panicle type and awns discloses a strong tendency for open panicle plants to be awned, or mostly awned, while in one case in sixty-five a line was homozygous open and awnless (see Table 24). No awned, side panicle type was found, although one line had awns dominant. From the $F_{2}$ and $F_{3}$ data it seems that the factors for awns and panicle type are linked. This linkage is not physiological, since open-panicled, awnless lines were recovered in $\mathrm{F}_{3}$.

TABLE 24.-Breeding Behavior for Panicle Type and Awns in $F_{3}$ Families of the Cross Sparrowbill with Victor and Reciprocal, Grown in 1924.

\begin{tabular}{l|c|c|c|c|c|c}
\hline \hline \multirow{2}{*}{$\begin{array}{c}\text { Type } \\
\text { of } \\
\text { Panicle }\end{array}$} & Awned & $\begin{array}{c}\text { Awns } \\
\text { Dominant }\end{array}$ & Like F2 & $\begin{array}{c}\text { Awnless } \\
\text { Dominant }\end{array}$ & Awnless & Total \\
\cline { 2 - 8 } & 5 & 29 & 27 & 3 & 1 & 65 \\
Open & 5 & 22 & 46 & 2 & & 75 \\
Seg. & 1 & 7 & 1 & 1 & 10 \\
\hline Side & & 52 & 80 & 6 & 2 & 150 \\
\hline Total & &
\end{tabular}


A study of inheritance was made in a cross between Sparrowbill and Victor oats. The characters studied were length of grain, color of grain, awns, and type of panicle. The Victor parent has long, black grain, strong, black twisted, geniculate awns, and open panicles; while the Sparrowbill parent has short, white grain, none or rery few awns, and a side panicle. The cross was made reciprocally and in no case was there a difference in segregation in the cross or the reciprocal.

Grain length appeared to be a very stable size character. The segregation as obtained for grain length, based on the number of $\mathrm{F}_{3}$ families which appeared to be homozygous, could be explained on a three factor basis, each factor when heterozygous having a greater effect than when homozygous, and the various factors interacting in a cumulative way. Black versus white grain was apparently dependent on a single factor pair. Open versus side panicle type appeared to be differentiated by two duplicate factors with open panicle dominant. The development of awns could not be explained on a single factor basis.

After determining the mode of inheritance of the individual characters, a study was made to determine any possible linkage in inheritance of the various characters. The study of the linkage of factors on the chromosome basis is of particular interest in relation to the mode of inheritance of size characters.

Considering the relation of grain length and color in $F_{2}$ it was found that there was practically no relation between these two char-

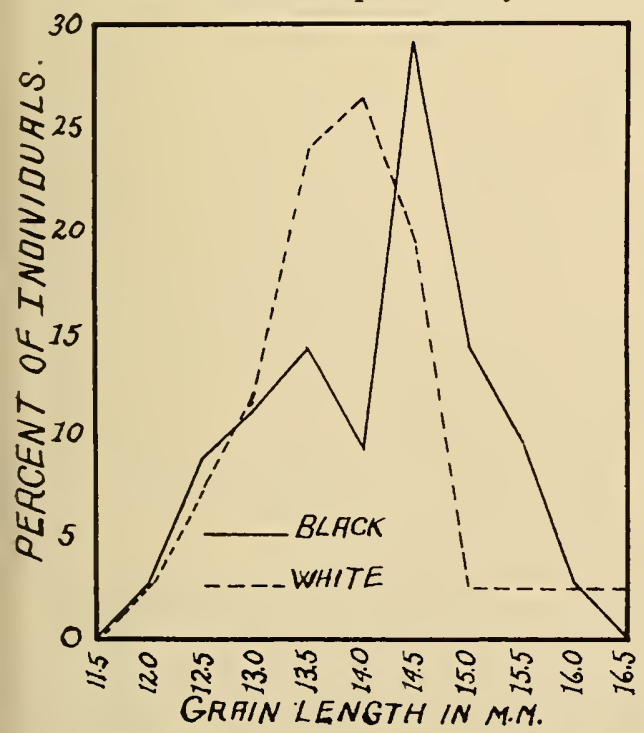
acters, as no significant differences in grain length were observed between black and white plants. The $\mathrm{F}_{3}$ families were grouped into three classes of grain, namely, homozygous black, homozygous white, and segregating for color. The mean length of grain of each of these groups was determined. In no case is there a significant difference between these means. Figure 1 presents graphically the mean length of grain of the $\mathrm{F}_{3}$ families homozygous for

Fig. 1.-Relation of Grain Length and Grainwhite and for black grains. Color in Individual $\boldsymbol{F}_{3}$ Families, Homozygous These facts seem to show Victor and Reciprocal. that there is no linkage be- 
tween the factor for grain color and a factor or factors for grain length.

Considering the relation of panicle type and length of grain, the data for $\mathrm{F}_{2}$ bring out the fact that in both years the $\mathrm{F}_{2}$ open panicle plants had longer grain than the side panicle plants. The differences for 1923 and 1924 were respectively $0.69 \pm 0.14$ and $0.74 \pm 0.14$, with odds of 1,050:1 and more than 1,350:1 that differences as great as the ones shown are not due to chance. For the $F_{3}$ families the differences are more striking, the homozygous open families having a mean length of grain $1.27 \pm 0.14$ millimeters longer than the homozygous side panicle families. Figure 2 presents the data for $F_{3}$ in the form of a chart. In this chart the length of grain of the homozygous open and homozygous side families is compared, and also the length of grain in families segregating in a ratio of $15: 1$ and $3: 1$ for open and side panicles. The chart brings out the fact that the families segregating 15:1 had a grain length longer on the average than the families segregating $3: 1$. The mean length of grain for the families segregating in the $15: 1$ and $3: 1$ ratios respectively was $14.18 \pm 0.07$ and $13.64 \pm 0.06$. The chances that these values are significantly different are extremely high. These data indicate that probably a factor for grain length is linked with each of the factors for panicle type.
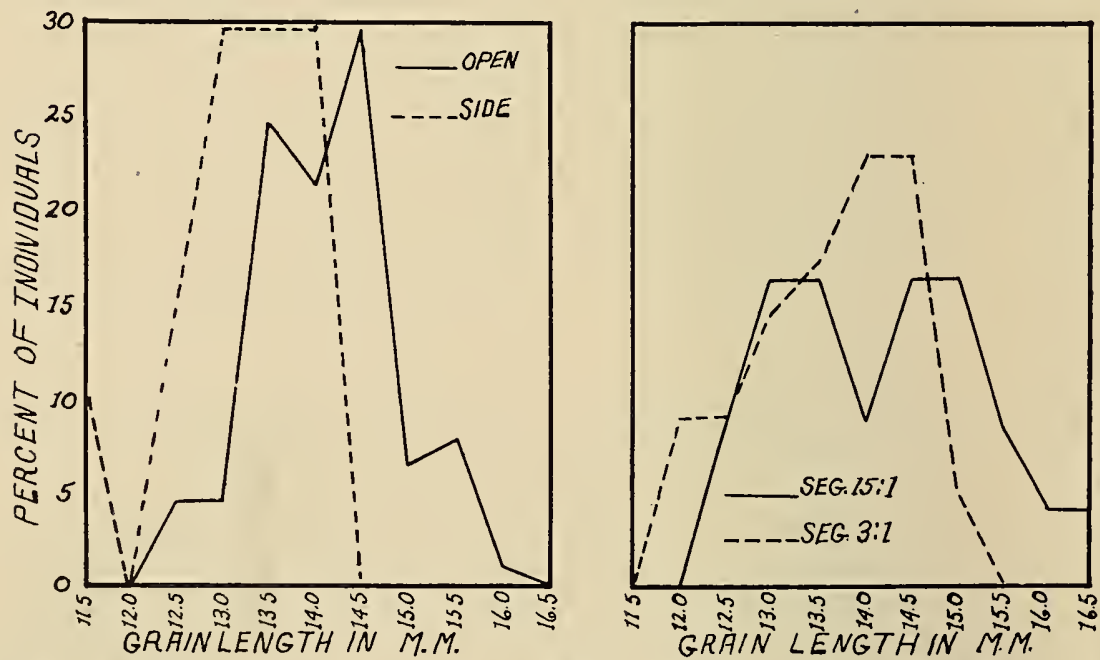

Fig. 2.-Relation of Grain Length and Panicle Type in Individual $F_{3}$ Families of the Cross Sparrowbill with Victor and Reciprocal. Left: Families Homozygous for Open and Side Panicles. Right: Families Segregating in Ratios of 15:1 or $3: 1$ for Open and Side Panicles. 
Since it is shown that probably there is a factor for grain length linked with each of the two factors for panicle type, this would place a factor, or a group of factors for length of grain, in each of the two linkage groups which contain factors for panicle type. A study of the relation of panicle type and grain color in the $F_{2}$ data and in the $\mathrm{F}_{3}$ breeding behavior shows that there was no relation between these characters. This would indicate that the factor for grain color is in a third linkage group.

A study of the relation of panicle type and awns indicates a rather close correlation between these two characters. In $F_{2}$ there was a strong tendency for the open panicle plants to be stronger awned than the side panicle plants, as is shown in Figure 3 . The $F_{3}$ data brought out the fact that homozygous open panicle families were inclined to be fully awned like the Victor parent. One family was tound, however, which was homozygous awnless and was breeding true for open panicle. Such a result proves that a cross-over took place, breaking the linkage between awns and open panicles. The homozygous side families on the other hand had fewer awns and showed a tendency to breed awnless, like the Sparrowbill parent. This suggests a linkage between at least one factor for awns and

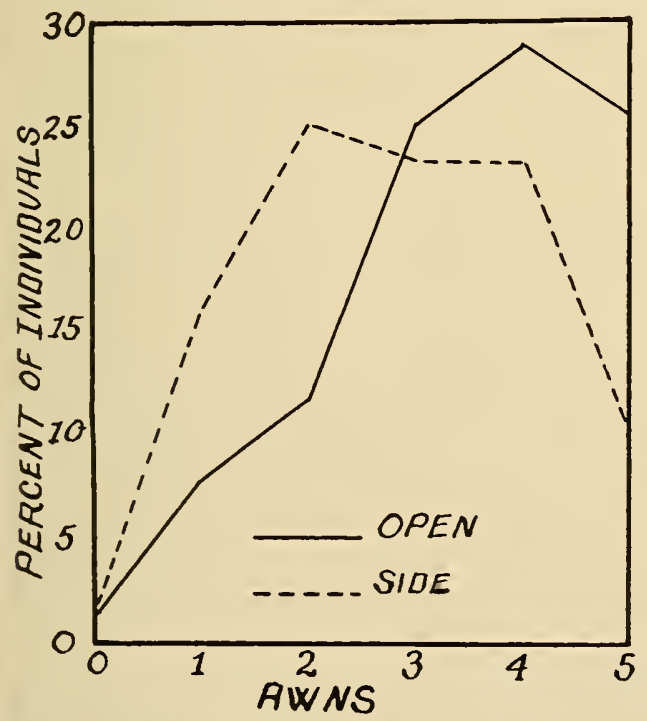

Fig. 3.-Relation of Panicle Type and Awn Development in $F_{2}$ Plants of the Cross Sparrowbill with Victor and Reciprocal Grown in 1923 and 1924. one of the factors for open panicles. One family breeding true for side panicle was classed as awns dominant, giving another indication of a crossover.

If a factor for awns is linked with a factor for panicle type, there should be some indication of relation between grain length and awns, since it has been shown that there in a relation between panicle type and length of grain. The data presented indicate that such is the case; that a fully awned condition and long grains tend to be associated. This relation in the $F_{2}$ families grown in 1923, as expressed by the correlation ration, was $\eta=0.358 \pm 0.024$, and in 1924 , 
$\eta=0.368 \pm 0.029$. For the $F_{3}$ families the value of $\eta$ was $0.469 \pm 0.043$ These values of $\eta$ indicate a rather close relation between awns and length of grain. From this it may be assumed that in at least one of the linkage groups in which there is a factor for panicle type and a factor or group of factors for grain length there is also a factor or factors for awns.

The other relation studied was between awns and color of grain.

The data are rather indefinite in $F_{2}$, since in 1923 there was an

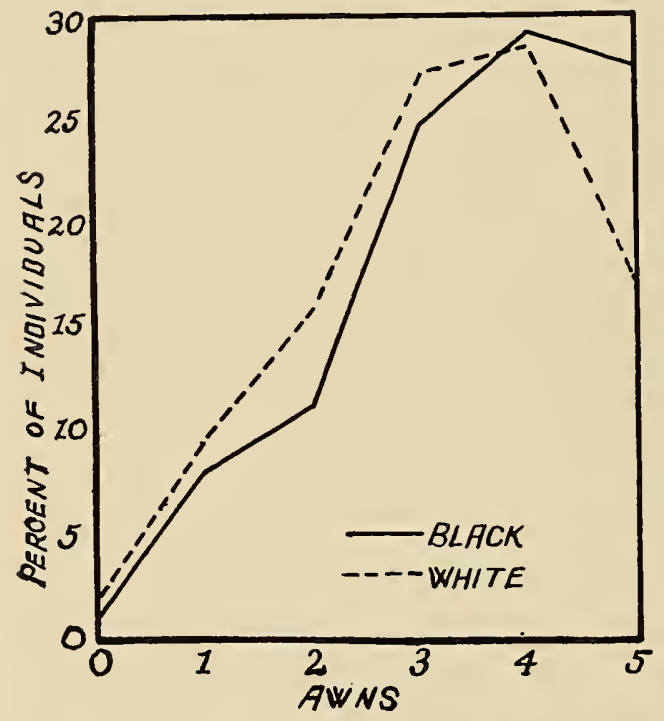

Fig. 4.-Relation of Color of Grain and Awn Development in $F_{2}$ Plants of the Cross Sparrowbill with Victor and Reciprocal Grown in 1923 and 1924. indication of linkage between black color and awns, while the probabilities of such a linkage in the 1924 material are rather small. Figure 4 presents the combined data for $F_{2}$, giving the percentage of black and white plants in the various awn classes. It is seen that there is little difference between the curves for black grain plants and the one for white plants, except that the line representing the white grain plants drops off sharply in the fully awned class. The $\mathrm{F}_{3}$ data indicate, however, that the families homozygous for black grain tend to be heavier awned than the families homozygous for white grain. Only two homozygous awnless families were grown in $F_{3}$ and these were segregating for color. Of the homozygous white grain families three were classed as fully awned. These facts make it rather doubtful that there is a linkage between the factor for color and a factor for awns. If any linkage is assumed it must be considered to be very loose.

\section{SUMMARY}

1.-A study was made of the inheritance of length of grain and other differential characters in a cross between Sparrowbill and Victor oats. The Victor parent had a mean length of the primary grain of 16.4 millimeters, black grain color, open panicle, and each primary grain carried a rather strong, black twisted, geniculate awn. 
The Sparrowbill, on the other hand, had a mean grain length of 11.5 millimeters, white grain color, side panicle, and none or very few of the grains were awned.

2.-All of the primary grains from the leading panicle of 117 plants of Victor grown on good soil in 1923 were removed in order from the base to the tip of the panicle and measured for length. From these data it was found that a sample of ten grains selected from all parts of the panicle gave approximately as accurate a measure of grain length for the panicle as did all of the grains in the panicle. It was also shown that grains at the tip of the panicle were longer than those at the base. A sample of ten grains, selected at random from the leading panicle was used as a sample from which to determine the length of grain for each plant studied.

3.-Each parent was grown on good and poor soil in order to study the influence of soil condition on length of grain. It was found that poor soil did not greatly reduce grain length although height and yield of plant were greatly reduced. This brings out the fact that, while grain length is variable, it is less variable than such characters as plant yield and height.

4.-The parent varieties differed in grain length by about 4.9 millimeters. The $F_{1}$ was intermediate for length of grain, although tending to approach the length of Victor. The $F_{2}$ variability for grain length was much greater than for either parent, the range being from the length of one parent to the length of the other. In $F_{s}$ two families from a total of a hundred and fifty were recovered with a mean grain length as short as Sparrowbill, and four with a mean length as great as Victor. Between these two extremes were found lines apparently homozygous for grain of intermediate length. The results obtained can be explained satisfactorily by the assumption that the parents differ by at least three main factors or groups of fictors for grain length.

5.-Color of grain was controlled by a single factor pair, black being dominate. Panicle type was controlled by two duplicate factors, one or both present in the dominant condition giving open panicles. Inheritance of awns was of a more complex nature and could not be explained by a single factor difference.

6.-It was found that there was no linkage between the factor for color of grain and any factors for length of grain. With each factor for panicle type is probably linked a factor, or group of factors, for grain length. At least one factor for awns is linked with a factor or factors for length of grain, and there was also linkage between 
a factor for panicle type and one for awns, as would be expected since length of grain and panicle type are associated.

7.-It was demonstrated that color of grain and paincle type were not associated and there was little or no relation between color and awns. The data indicate three linkage groups, one containing a factor for color and possibly a factor for awns. A second group contains a factor for panicle type, together with a factor, or group of factors, for the characters length of grain and awns, respectively, while the third group contains a factor for panicle type and a factor or factors for grain length. 


\section{LITERATURE CITATIONS}

CAPORN, A. ST. CLAIR

1918. AN ACCOUNT OF AN EXPERIMENT TO DETERMINE THE HEREDITY OF EARLY AND LATE RIPENING IN AN OAT CROSS. Jour. Genetics 7: 247-257.

EAST, E. M.

1916. STUDIES ON SIZE INHERITANCE IN NICOTIANA. Genetics 1: 164-176.

ETHRIDGE, W. C.

1916. A CLASSIFICATION OF THE VARIETIES OF CULTIVATED OATS. N. Y. Cornell Agr. Exp. Sta. Mem. 10.

FRASER, A. C.

1919. THE INHERITANCE OF THE WEAK AWN IN CERTAIN AVENA CROSSES AND ITS RELATION TO OTHER CHARCTERS OF THE OAT GRAIN. N. Y. Cornell Agr. Exp. Sta. Mem .23.

GAINES, E. F.

1917. INHERITANCE IN WHEAT, BARLEY, AND OAT HYBRIDS. Wash. Agr. Exp. Sta. Bul. 135.

GARBER, R. J.

1922. INHERITANCE AND YIELD WITH PARTICULAR REFERENCE TO RUST RESISTANCE AND PANICLE TYPE IN OATS. Minn. Agr. Exp. Sta. Tech. Bul. 7.

GRIFFEE, FRED

1925. CORRELATED INHERITANCE OF BOTANICAL CHARACTERS IN BARLEY AND MANNER OF REACTION TO HELMINTHOSPORIUM SATIVUM. Jour. Agr. Res. 30: 915-935.

HAYES, H. K. and GARBER, R. J.

1921. BREEDING CROP PLANTS. pp. 89-98. McGraw-Hill Book Company, New York.

LINDSTROM, E. W.

1924. A GENETIC LINKAGE BETWEEN SIZE AND COLOR FACTORS IN THE TOMATO. Science, N. S. 60: 182-183.

LOVE, H. H.

1924. A MODIFICATION OF STUDENT'S TABLE FOR USE IN INTERPRETING EXPERIMENTAL RESULTS. Jour. Amer. Soc. Agron. 16: $68-73$. and CRAIG, W. T.

1918-a. THE RELATION BETWEEN COLOR AND OTHER CHARACTERS IN CERTAIN AVENA CROSSES. Amer. Not. 52: 369-383.

1918-b. SMALL GRAIN INVESTIGATIONS. Jour. Heredity 9: 67-76.

LOVE, H. H. and FRASER, A. C.

1917. THE INHERITANCE OF THE WEAK AWN IN CERTAIN AVENA CROSSES. Amer. Nat. 51: 481-493.

NILSSON-EHLE, H.

1908. EINIGE ERGEBNISSE VON KREUZUNGEN BEI HAFER UND WEIZEN. Botan. Notiser, Lund., pp. 257-298.

1909. KREUZUNGSUNTERSUCHUNGEN AN HAFER UND WEIZEN. Lunds Univ. Arsskr. N. F. Afd. 2, Bd. 5, Rr. 2, pp. 122.

NORTON, J. B.

1907. NOTES ON BREEDING OATS. Amer. Breeders Asoc. 3: 280-285.

YAX, KARL

1923. THE ASSOCIATION OF SIZE DIFFERENCES WITH SEED-COAT PATTERN AND PIGMENTATION IN PHASEOLUS VULGARIA. Genetics 8: 552-560. 
SURFACE, FRANK M.

1916. STUDIES ON OAT BREEDING. III. On the inheritance of certain glume characters in the cross Avena fatua $\mathbf{x} \mathbf{A}$. sativa var. Kherson. Genetics 1: 252-286.

WILSON, JOHN H.

1907. THE HYBRIDIZATION OF CEREALS. Jour. Agr. Sci. 2: 68-88.

WAKABAYASHI, S.

1921. A STUDY OF HYBRID OATS AVENA STERILIS $X$ AVENA ORIENTALIS. Jour. Amer. Soc. Agron. 13: 259-266.

ZINN, JACOB and SURFACE, F. IM.

1917. STUDIES ON OAT BREEDING. V. The $F_{1}$ and $F_{2}$ generation of a cross between a naked and a hulled oat. Jour. Agr. Research 10: 293-312. 


\section{APPENDIX}




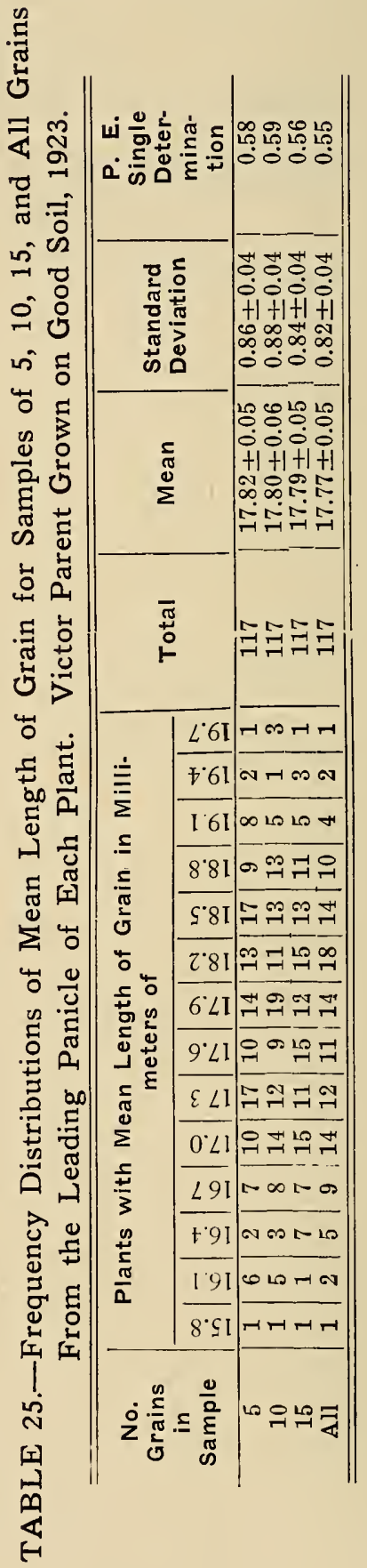


TABLE 26.-Progressive Differences in Mean Length of Grain, by Groups of Five, from the Base to the Tip of the Panicle. Victor Parent Grown on Good Soil, 1923.

\begin{tabular}{|c|c|c|c|}
\hline $\begin{array}{c}\text { Group No. } \\
\text { (5 Grains } \\
\text { per } \\
\text { Group) }\end{array}$ & $\begin{array}{c}\text { Number } \\
\text { of } \\
\text { Plants }\end{array}$ & $\begin{array}{l}\text { Approximate } \\
\text { Number of } \\
\text { Grains on } \\
\text { Leading } \\
\text { Panicle }\end{array}$ & $\begin{array}{l}\text { Mean } \\
\text { Length of } \\
\text { Grains in } \\
\text { Millimeters }\end{array}$ \\
\hline $\begin{array}{l}1 \\
2 \\
3\end{array}$ & $\begin{array}{l}9 \\
9 \\
9\end{array}$ & $\begin{array}{l}15 \\
15 \\
15\end{array}$ & $\begin{array}{l}16.9 \pm 0.2 \\
17.0 \pm 0.2 \\
18.0 \pm 0.2\end{array}$ \\
\hline $\begin{array}{l}1 \\
2 \\
3 \\
4\end{array}$ & $\begin{array}{l}11 \\
11 \\
11 \\
11\end{array}$ & $\begin{array}{l}20 \\
20 \\
20 \\
20\end{array}$ & $\begin{array}{l}16.9 \pm 0.2 \\
17.2 \pm 0.1 \\
17.3 \pm 0.2 \\
17.9 \pm 0.2\end{array}$ \\
\hline $\begin{array}{l}1 \\
2 \\
3 \\
4 \\
5\end{array}$ & $\begin{array}{l}19 \\
19 \\
19 \\
19 \\
19\end{array}$ & $\begin{array}{l}25 \\
25 \\
25 \\
25 \\
25\end{array}$ & $\begin{array}{l}17.2 \pm 0.1 \\
17.4 \pm 0.1 \\
17.4 \pm 0.1 \\
17.9 \pm 0.2 \\
18.2 \pm 0.2\end{array}$ \\
\hline $\begin{array}{l}1 \\
2 \\
3 \\
4 \\
5 \\
6\end{array}$ & $\begin{array}{l}21 \\
21 \\
21 \\
21 \\
21 \\
21\end{array}$ & $\begin{array}{l}30 \\
30 \\
30 \\
30 \\
30 \\
30\end{array}$ & $\begin{array}{l}17.7 \pm 0.1 \\
17.7 \pm 0.1 \\
17.7 \pm 0.1 \\
17.8 \pm 0.1 \\
18.6 \pm 0.1 \\
18.6 \pm 0.1\end{array}$ \\
\hline $\begin{array}{l}1 \\
2 \\
3 \\
4 \\
5 \\
6 \\
7\end{array}$ & $\begin{array}{l}21 \\
21 \\
21 \\
21 \\
21 \\
21 \\
21\end{array}$ & $\begin{array}{l}35 \\
35 \\
35 \\
35 \\
35 \\
35 \\
35\end{array}$ & $\begin{array}{l}17.2 \pm 0.1 \\
17.5 \pm 0.2 \\
17.5 \pm 0.1 \\
17.8 \pm 0.1 \\
18.0 \pm 0.2 \\
18.3 \pm 0.2 \\
18.4 \pm 0.2\end{array}$ \\
\hline $\begin{array}{l}1 \\
2 \\
3 \\
4 \\
5 \\
6 \\
7 \\
8\end{array}$ & $\begin{array}{l}13 \\
13 \\
13 \\
13 \\
13 \\
13 \\
13 \\
13\end{array}$ & $\begin{array}{l}40 \\
40 \\
40 \\
40 \\
40 \\
40 \\
40 \\
40\end{array}$ & $\begin{array}{l}17.3 \pm 0.2 \\
17.2 \pm 0.2 \\
17.4 \pm 0.2 \\
17.8 \pm 0.2 \\
17.5 \pm 0.1 \\
17.9 \pm 0.2 \\
18.4 \pm 0.2 \\
18.6 \pm 0.2\end{array}$ \\
\hline $\begin{array}{l}1 \\
2 \\
3 \\
4 \\
5 \\
6 \\
7 \\
8 \\
9\end{array}$ & $\begin{array}{l}11 \\
11 \\
11 \\
11 \\
11 \\
11 \\
11 \\
11 \\
11\end{array}$ & $\begin{array}{l}45 \\
45 \\
45 \\
45 \\
45 \\
45 \\
45 \\
45 \\
45\end{array}$ & $\begin{array}{l}17.4 \pm 0.2 \\
17.6 \pm 0.2 \\
17.7 \pm 0.1 \\
17.7 \pm 0.1 \\
17.7 \pm 0.2 \\
17.9 \pm 0.2 \\
18.1 \pm 0.2 \\
18.2 \pm 0.2 \\
18.3 \pm 0.2\end{array}$ \\
\hline $\begin{array}{r}1 \\
2 \\
3 \\
4 \\
5 \\
6 \\
7 \\
8 \\
9 \\
10\end{array}$ & $\begin{array}{l}9 \\
9 \\
9 \\
9 \\
9 \\
9 \\
9 \\
9 \\
9 \\
9\end{array}$ & $\begin{array}{l}50 \\
50 \\
50 \\
50 \\
50 \\
50 \\
50 \\
50 \\
50 \\
50\end{array}$ & $\begin{array}{l}17.3 \pm 0.2 \\
17.6 \pm 0.2 \\
17.4 \pm 0.2 \\
17.7 \pm 0.2 \\
17.9 \pm 0.2 \\
17.8 \pm 0.2 \\
17.7 \pm 0.3 \\
18.0 \pm 0.3 \\
18.0 \pm 0.3\end{array}$ \\
\hline
\end{tabular}


TABLE 27.-Length of Grain of Sparrowbill Parent Grown in Various Plots, 1924.

\begin{tabular}{|c|c|c|c|c|c|c|c|c|}
\hline \multirow[t]{2}{*}{$\begin{array}{l}1924 \text { Row } \\
\text { Number }\end{array}$} & \multicolumn{4}{|c|}{$\begin{array}{c}\text { Grain } \\
\text { Lentgh of } \\
\text { Plants } \\
\text { in Millimeters }\end{array}$} & \multirow[t]{2}{*}{ 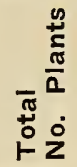 } & \multirow[t]{2}{*}{$\begin{array}{l}\text { Mean } \\
\text { Length of } \\
\text { Grain in } \\
\text { Milli- } \\
\text { meters }\end{array}$} & \multirow[t]{2}{*}{ 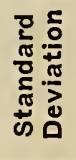 } & \multirow[t]{2}{*}{$\begin{array}{c}\text { Coefficient } \\
\text { of } \\
\text { Variability }\end{array}$} \\
\hline & 10| & $11 \mid$ & 12 & 13 & & & & \\
\hline $937-38 \mathrm{~S}$ & & 5 & 24 & & 29 & $11.83 \pm 0.05$ & 0.38 & $3.21 \pm 0.20$ \\
\hline $943-44 \mathrm{~S}$ & & 5 & 15 & 2 & 22 & $11.86 \pm 0.08$ & .55 & $4.64 \pm 0.33$ \\
\hline $953-54 \mathrm{~S}$ & & 8 & 18 & & 26 & $11.69 \pm 0.06$ & .46 & $3.93 \pm 0.26$ \\
\hline $963-64 \mathrm{~S}$ & 2 & 24 & 15 & & 41 & $11.32 \pm 0.06$ & .56 & $4.95 \pm 0.26$ \\
\hline $973-74 \mathrm{~S}$ & 2 & 18 & 18 & & 38 & $11.42 \pm 0.07$ & .59 & $5.17 \pm 0.28$ \\
\hline $983-84 S$ & & 24 & 15 & & 39 & $11.39 \pm 0.05$ & .49 & $4.30 \pm 0.23$ \\
\hline $997-98 \mathrm{~S}$ & & 21 & 18 & & 39 & $11.46 \pm 0.05$ & .50 & $4.36 \pm 0.24$ \\
\hline $1011-12 \mathrm{~S}$ & & 25 & 11 & & 36 & $11.31 \pm 0.05$ & .46 & $4.07 \pm 0.23$ \\
\hline $1025-26 \mathrm{~S}$ & & 13 & 25 & & 38 & $11.66 \pm 0.05$ & .47 & $4.03 \pm 0.22$ \\
\hline $1039-40 \mathrm{~S}$ & & 8 & 25 & & 33 & $11.76 \pm 0.05$ & .43 & $3.66 \pm 0.21$ \\
\hline $1053-54 \mathrm{~S}$ & & 17 & 16 & 1. & 34 & $11.53 \pm 0.06$ & .55 & $4.77 \pm 0.28$ \\
\hline $1067-68 \mathrm{~S}$ & 2 & 28 & 12 & 1 & 43 & $11.28 \pm 0.06$ & .58 & $5.14 \pm 0.26$ \\
\hline $1081-82 \mathrm{~S}$ & & 24 & 12 & & 36 & $11.33 \pm 0.05$ & .47 & $4.15 \pm 0.23$ \\
\hline $1095-96 \mathrm{~S}$ & 1 & 30 & 7 & & 38 & $11.16 \pm 0.05$ & .43 & $3.85 \pm 0.21$ \\
\hline $1109-1110 \mathrm{~S}$ & 2 & 21 & 11 & & 34 & $11.27 \pm 0.07$ & .56 & $4.97 \pm 0.29$ \\
\hline $1123-24 \mathrm{~S}$ & & 22 & 19 & & 41 & $11.46 \pm 0.05$ & .50 & $4.36 \pm 0.23$ \\
\hline $1137-38 \mathrm{~S}$ & & 19 & 15 & & 34 & $11.44 \pm 0.06$ & .50 & $4.37 \pm 0.25$ \\
\hline $1151-52 \mathrm{~S}$ & & 4 & 24 & 1 & 29 & $11.90 \pm 0.05$ & .40 & $3.36 \pm 0.21$ \\
\hline $1165-66 \mathrm{~S}$ & 2 & 20 & 11 & & 33 & $11.27 \pm 0.07$ & .57 & $5.06 \pm 0.30$ \\
\hline $1179-80 \mathrm{~S}$ & 7 & 20 & 11 & & 38 & $11.11 \pm 0.07$ & .68 & $6,12 \pm 0.33$ \\
\hline $1193-94 \mathrm{~S}$ & i) & 12 & 23 & 1 & 37 & $11.65 \pm 0.06$ & .58 & $4.98 \pm 0.28$ \\
\hline $1207-08 \mathrm{~S}$ & 1 & 15 & 22 & & 38 & $11.55 \pm 0.06$ & .55 & $4.76 \pm 0.26$ \\
\hline $1221-22 \mathrm{~S}$ & 1 & 14 & 21 & & 36 & $11.56 \pm 0.06$ & .55 & $4.76 \pm 0.27$ \\
\hline $1235-36 \mathrm{~S}$ & 2 & 14 & 19 & & 35 & $11.49 \pm 0.07$ & .60 & $5.22 \pm 0.30$ \\
\hline $1249-50 \mathrm{~S}$ & & 13 & 18 & & 31 & $11.58 \pm 0.06$ & .49 & $4.23 \pm 0.26$ \\
\hline $1263-64 \mathrm{~S}$ & 2 & 18 & 21 & 1 & 42 & $11.50 \pm 0.07$ & .63 & $5.48 \pm 0.29$ \\
\hline $1277-78 \mathrm{~S}$ & 1 & 23 & 17 & & 41 & $11.39 \pm 0.06$ & .54 & $4.74 \pm 0.25$ \\
\hline $1291-92 \mathrm{~S}$ & 1 & 14 & 24 & & 39 & $11.59 \pm 0.06$ & .54 & $4.66 \pm 0.25$ \\
\hline $1305-06 \mathrm{~S}$ & & 20 & 20 & & 40 & $11.50 \pm 0.05$ & .50 & $4.35 \pm 0.23$ \\
\hline $1319-20 \mathrm{~S}$ & 2 & 29 & 9 & 1 & 41 & $11.22 \pm 0.06$ & .56 & $4.99 \pm 0.26$ \\
\hline $1331-32 \mathrm{~S}$ & & 20 & 16 & & 36 & $11.44 \pm 0.06$ & .50 & $4.37 \pm 0.25$ \\
\hline $1347-48 \mathrm{~S}$ & & 15 & 18 & 1 & 34 & $11.59 \pm 0.06$ & .55 & $4.75 \pm 0.27$ \\
\hline $1361-62 \mathrm{~S}$ & & 13 & 21 & 1 & 35 & $11.66 \pm 0.06$ & .53 & $4.55 \pm 0.26$ \\
\hline $1375-76 \mathrm{~S}$ & & 13. & 20 & 1) & 34 & $11.65 \pm 0.06$ & .54 & $4.64 \pm 0.27$ \\
\hline $1389-90 \mathrm{~S}$ & & 6 & 26 & 1 & 33 & $11.85 \pm 0.05$ & .44 & $3.71 \pm 0.22$ \\
\hline $1403.04 \mathrm{~S}$ & & 25 & 12 & & 37 & $11.32 \pm 0.05$ & .47 & $4.15 \pm 0.23$ \\
\hline
\end{tabular}


TABLE 28.-Length of Grain of Victor Parent Grown in Various Plots, 1924.

\begin{tabular}{|c|c|c|c|c|c|c|c|c|c|}
\hline \multirow[t]{2}{*}{$\begin{array}{l}1924 \text { Row } \\
\text { Number }\end{array}$} & \multicolumn{5}{|c|}{$\begin{array}{c}\text { Grain } \\
\text { Lentgh of } \\
\text { Plants } \\
\text { in Millimeters }\end{array}$} & \multirow[t]{2}{*}{ 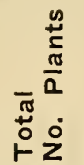 } & \multirow{2}{*}{$\begin{array}{l}\text { Mean } \\
\text { Length of } \\
\text { Grain in } \\
\text { Milli- } \\
\text { meters }\end{array}$} & \multirow[t]{2}{*}{ 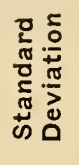 } & \multirow[t]{2}{*}{$\begin{array}{c}\text { Coefficient } \\
\text { of } \\
\text { Variability }\end{array}$} \\
\hline & $15 \mid$ & $16 \mid$ & $17 \mid$ & 18 & $\overline{19}$ & & & & \\
\hline $935-36 \mathrm{~S}$ & 1 & 23 & 9 & & & 33 & $16.24 \pm 0.06$ & 0.49 & $3.02 \pm 0.18$ \\
\hline $941-42 \mathrm{~S}$ & 1 & 18 & 7 & 3 & & 29 & $16.41 \pm 0.09$ & .72 & $4.39 \pm 0.27$ \\
\hline $951-52 \mathrm{~S}$ & 5 & 26 & 3 & & & 34 & $15.94 \pm 0.06$ & .48 & $3.01 \pm 0.17$ \\
\hline $961-62 \mathrm{~S}$ & 8 & 18 & 7 & & & 33 & $15.97 \pm 0.08$ & .67 & $4.20 \pm 0.25$ \\
\hline $971-72 \mathrm{~S}$ & 3 & 21 & 16 & & & 40 & $16.33 \pm 0.07$ & .61 & $3.74 \pm 0.20$ \\
\hline $981-82 \mathrm{~S}$ & & 18 & 21 & 1 & & 40 & $16.58 \pm 0.06$ & .54 & $3.26 \pm 0.17$ \\
\hline $995-96 \mathrm{~S}$ & 1 & 14 & 18 & 4 & & 37 & $16.68 \pm 0.08$ & .70 & $4.20 \pm 0.23$ \\
\hline $1009-10 \mathrm{~S}$ & 2 & 27 & 7 & & & 36 & $16.14 \pm 0.05$ & .48 & $2.97 \pm 0.17$ \\
\hline $1023-24 \mathrm{~S}$ & 2 & 23 & 8 & & & 33 & $16.18 \pm 0.06$ & .52 & $3.21 \pm 0.19$ \\
\hline $1037-38 \mathrm{~S}$ & & 19 & 11 & & & 30 & $16.37 \pm 0.06$ & .48 & $2.93 \pm 0.18$ \\
\hline $1051-52 \mathrm{~S}$ & & 16 & 14 & 1 & & 31 & $16.52 \pm 0.07$ & .56 & $3.39 \pm 0.21$ \\
\hline $1065-66 \mathrm{~S}$ & & 28 & 10 & & & 38 & $16.26 \pm 0.05$ & .44 & $2.71 \pm 0.15$ \\
\hline $1079-80 \mathrm{~S}$ & & 15 & 22 & 1 & & 38 & $16.63 \pm 0.06$ & .54 & $3.25 \pm 0.18$ \\
\hline $1093-94 \mathrm{~S}$ & 1 & 9 & 24 & 2 & & 36 & $16.75 \pm 0.07$ & .60 & $3.58 \pm 0.20$ \\
\hline 1107-08S & 1 & 16 & 23 & 2 & & 42 & $16.62 \pm 0.06$ & .62 & $3.73 \pm 0.19$ \\
\hline $1121-22 \mathrm{~S}$ & & 13 & 22 & 2 & & 37 & $16.70 \pm 0.06$ & .56 & $3.35 \pm 0.19$ \\
\hline $1135-36 \mathrm{~S}$ & 1 & 20 & 14 & 1 & & 36 & $16.42 \pm 0.07$ & .60 & $3.65 \pm 0.21$ \\
\hline $1149-50 \mathrm{~S}$ & 1 & 15 & 6 & 1 & & 23 & $16.30 \pm 0.09$ & .62 & $3.80 \pm 0.27$ \\
\hline $1163-64 \mathrm{~S}$ & 3 . & 26 & 10 & 1 & & 40 & $16.23 \pm 0.06$ & .61 & $3.76 \pm 0.20$ \\
\hline $1177-78 \mathrm{~S}$ & 1 & 18 & 13 & & & 32 & $16.38 \pm 0.07$ & .55 & $3.36 \pm 0.20$ \\
\hline $1191-92 \mathrm{~S}$ & 2 & 19 & 11 & 1 & & 33 & $16.33 \pm 0.08$ & .64 & $3.92 \pm 0.23$ \\
\hline $1205-06 \mathrm{~S}$ & 4 & 26 & 14 & 1 & & 45 & $16.27 \pm 0.07$ & .65 & $4.00 \pm 0.20$ \\
\hline $1219-20 \mathrm{~S}$ & 1 & 13 & 20 & 4 & & 38 & $16.71 \pm 0.08$ & .69 & $4.13 \pm 0.23$ \\
\hline $1233-34 \mathrm{~S}$ & & 28 & 13 & 1. & & 42 & $16.36 \pm 0.06$ & .53 & $3.24 \pm 0.17$ \\
\hline $1247-48 \mathrm{~S}$ & 3 & 26 & 4 & & & 33 & $16.03 \pm 0.05$ & .46 & $2,87 \pm 0.17$ \\
\hline $1261-62 \mathrm{~S}$ & 1 & 32 & 2 & & & 35 & $16.03 \pm 0.03$ & .29 & $1.81 \pm 0.10$ \\
\hline $1275-76 \mathrm{~S}$ & & 33 & 6 & 1 & & 40 & $16.20 \pm 0.05$ & .46 & $2.84 \pm 0.15$ \\
\hline $1289-90 \mathrm{~S}$ & & 25 & 13 & 1 & & 39 & $16.39 \pm 0.06$ & .54 & $3.29 \pm 0.18$ \\
\hline $1303-04 \mathrm{~S}$ & 3 & 20 & 9 & 1 & & 33 & $16.24 \pm 0.08$ & .65 & $4.00 \pm 0.23$ \\
\hline 1317-18S & 3 & 29 & 5 & & & 37 & $16.05 \pm 0.05$ & .46 & $2.86 \pm 0.16$ \\
\hline $1329-30 \mathrm{~S}$ & 2 & 19 & 13 & & & 34 & $16.32 \pm 0.07$ & .58 & $3.55 \pm 0.21$ \\
\hline $1345-46 \mathrm{~S}$ & 2 & 14 & 14 & 2 & 1 & 33 & $16.58 \pm 0.10$ & .82 & $4.95 \pm 0.29$ \\
\hline $1359-60 \mathrm{~S}$ & 2 & 23 & 15 & & & 40 & $16.33 \pm 0.06$ & .57 & $3.49 \pm 0.19$ \\
\hline $1373-74 \mathrm{~S}$ & 2 & 16 & 18 & & & 36 & $16.44 \pm 0.07$ & .60 & $3.65 \pm 0.21$ \\
\hline $1387-88 \mathrm{~S}$ & & 25 & 11 & 1 & & 37 & $16.35 \pm 0.06$ & .53 & $3.24 \pm 0.18$ \\
\hline $1401-02 \mathrm{~S}$ & & 16 & 22 & & & 38 & $16.58 \pm 0.05$ & .49 & $2.96 \pm 0.16$ \\
\hline
\end{tabular}




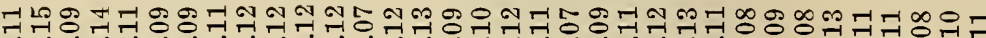

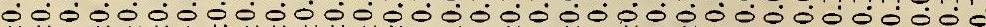
$+1+1+1+1+1+1+1+1+1+1+1+1+1+1+1+1+1+1+1+1+1+1+1+1+1+1+1+1+1+1+1+1+1+$ 닥 ๙ का

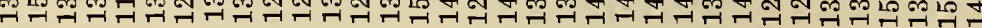

范㐫离站

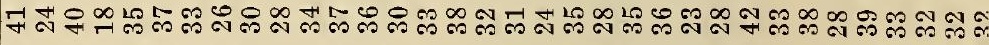
io

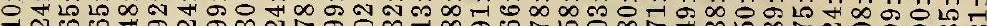
+

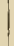

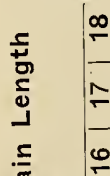

त)

心

동

З

$\pm$

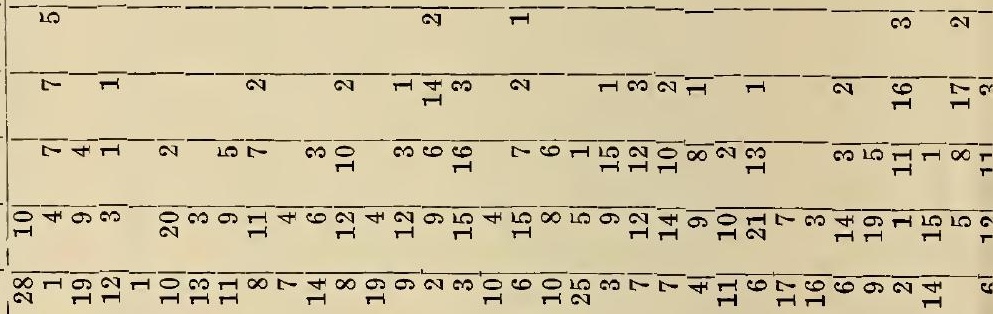

怘

$\frac{\pi}{2}$

$\bar{n} .5$

an $\left.\right|^{\infty}$

$\leftarrow \stackrel{\circ}{\circ}$

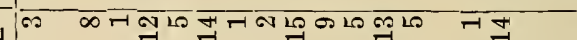

¿

$=$

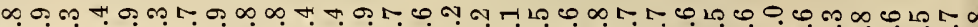

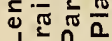
ن $\rightarrow \frac{0}{0} 0$

$\dot{I}$

ๆ ‘்

$\dot{z}$

3

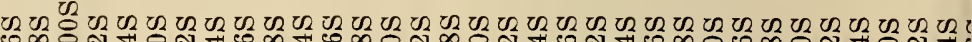
अ

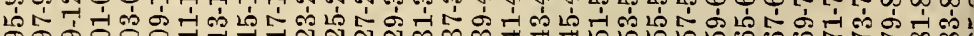
क\%

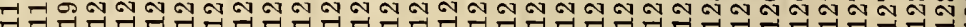




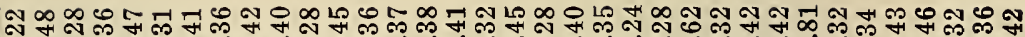

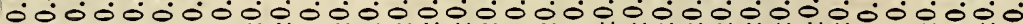
$+1+1+1+1+1+1+1+1+1+1+1+1+1+1+1+1+1+1+1+1+1+1+1+1+1+1+1+1+1+1+1+1+1+1+1$

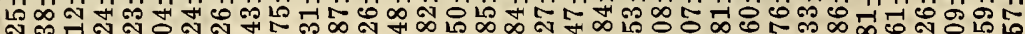

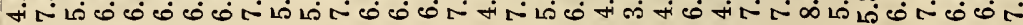

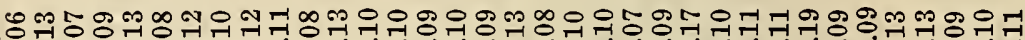

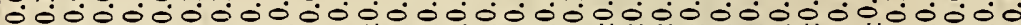
$+1+1+1+1+1+1+1+1+1+1+1+1+1+1+1+1+1+1+1+1+1+1+1+1+1+1+1+1+1+1+1+1+1+1+1$

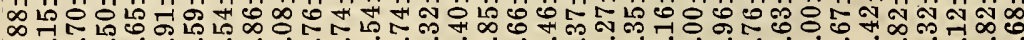
๓

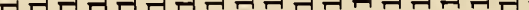

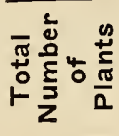

F్ㄷำ

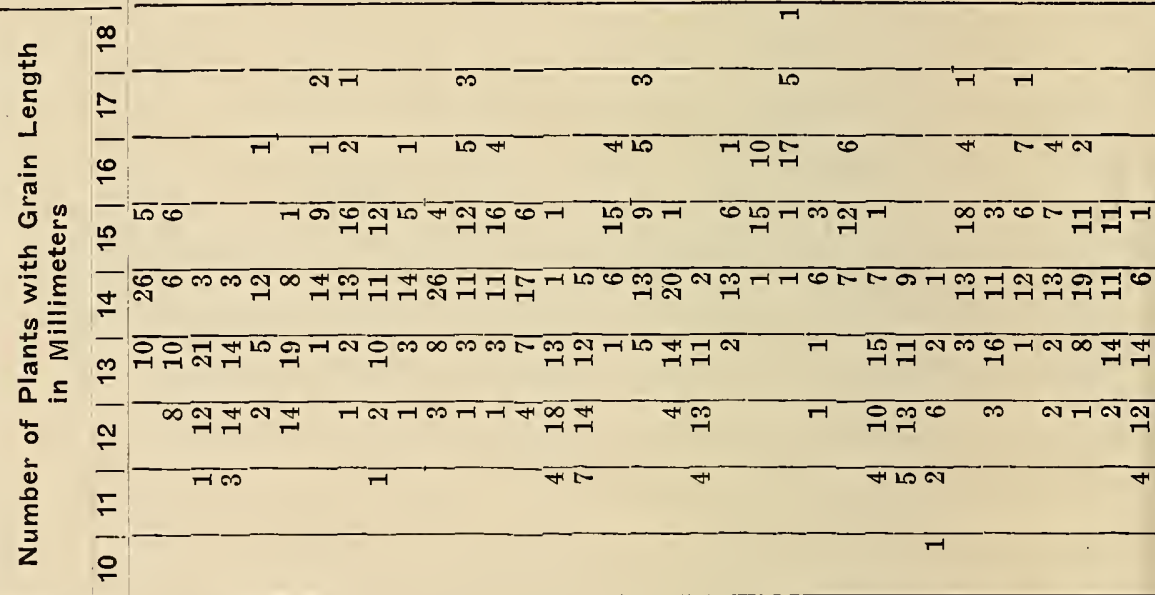

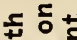

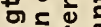

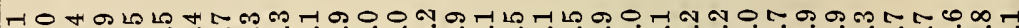
స ब行 $\frac{\pi}{0}$

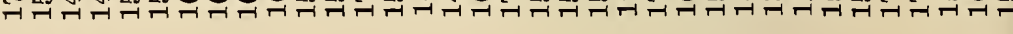

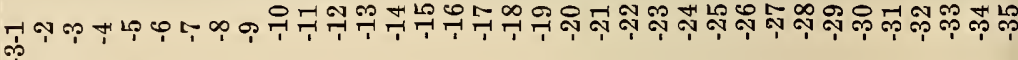

$\dot{I}$

$\dot{z}$ के

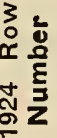

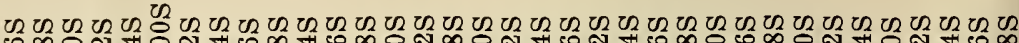

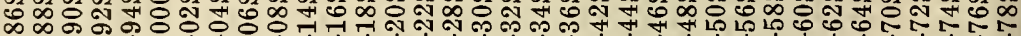
的方的

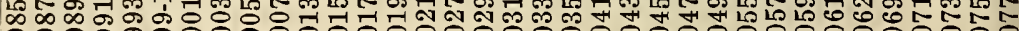
๙ 


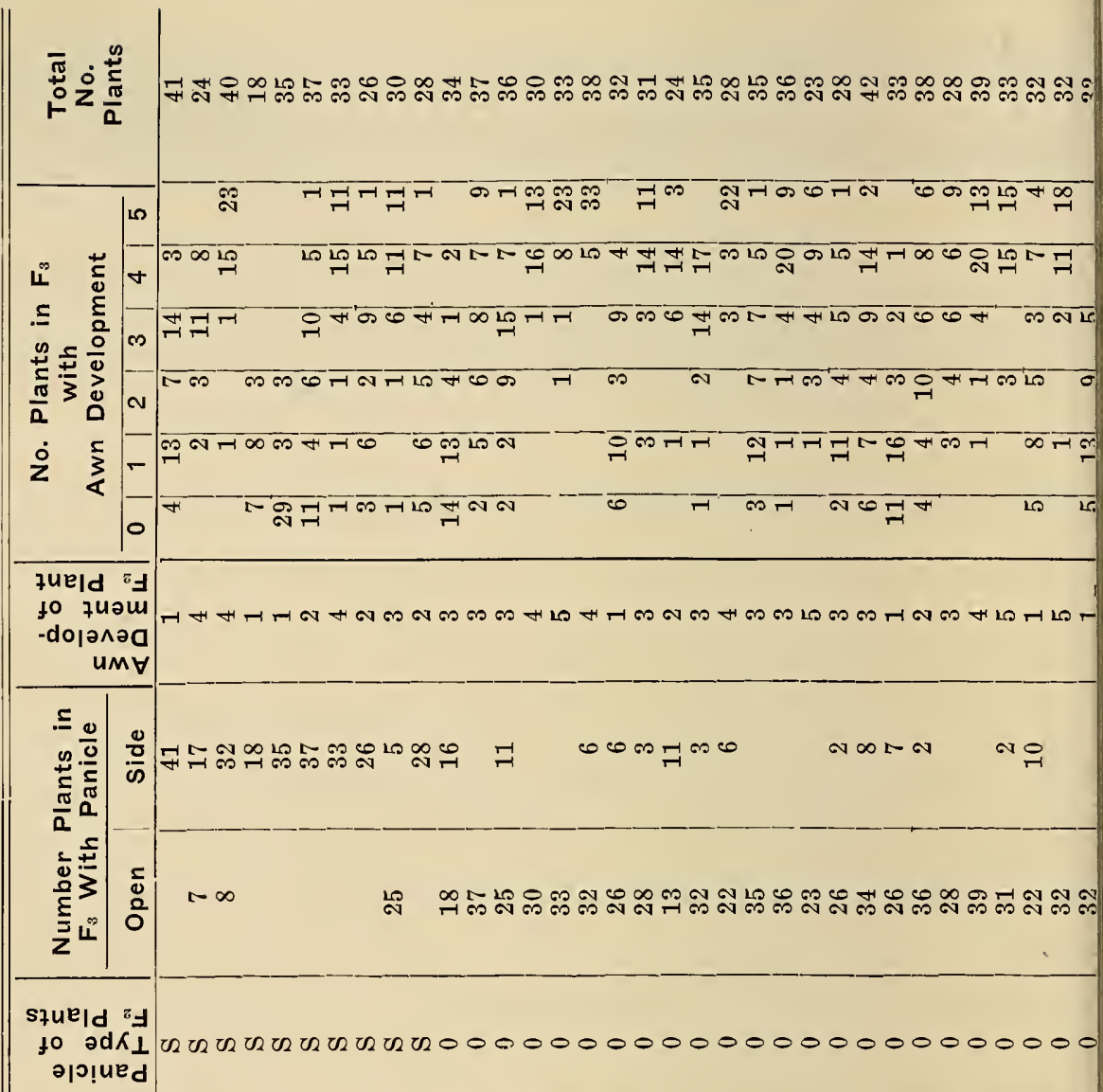

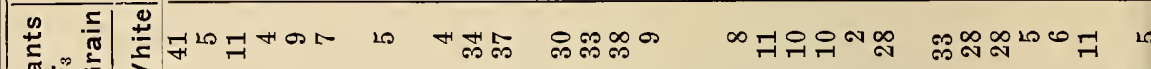
䒕 믄

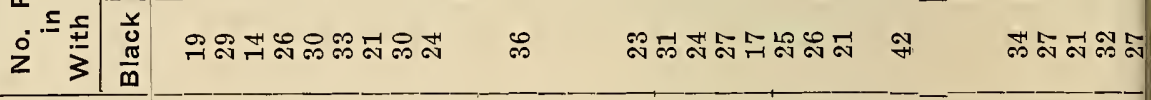

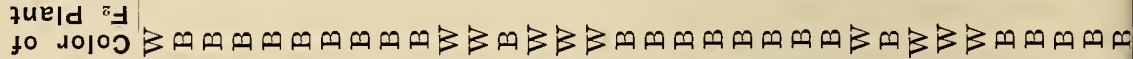
u!̣edり zं $\quad$ 움 I

$\dot{z}$

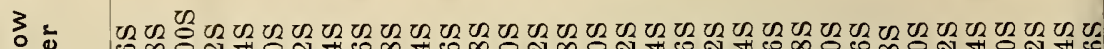
๔. ₹ 峁 


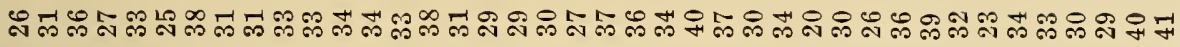

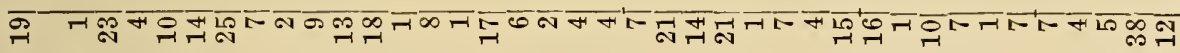

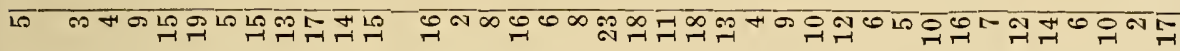

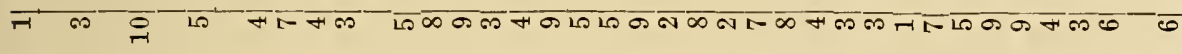

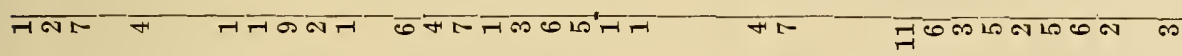

की

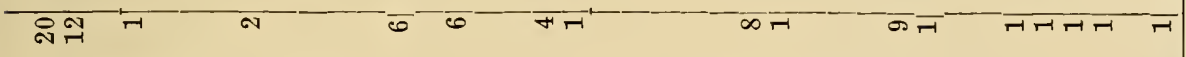

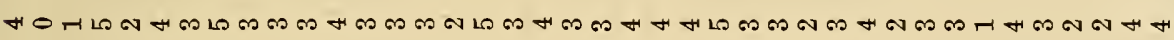

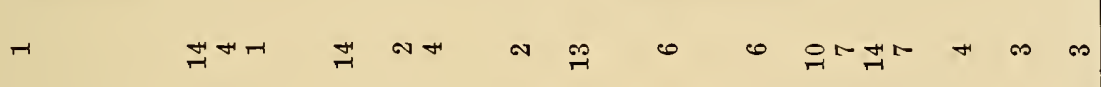

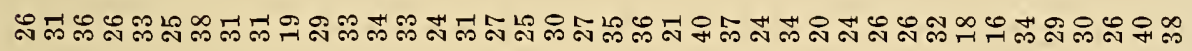

0000000000000000000000000000000000000000

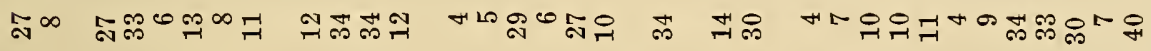

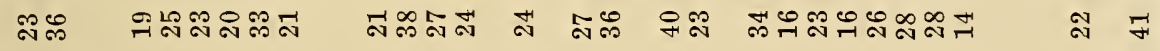

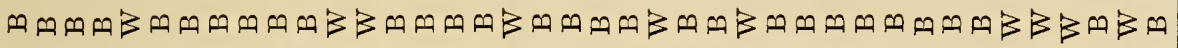

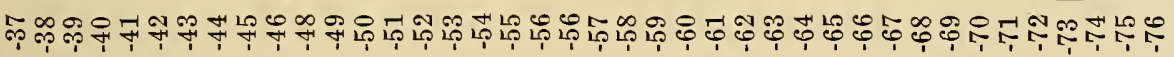

U్ ॠ ต่ ग స్ ה - 


\begin{tabular}{|c|c|c|}
\hline \multicolumn{2}{|c|}{ 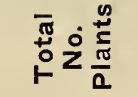 } & 氙战 \\
\hline \multirow{4}{*}{ 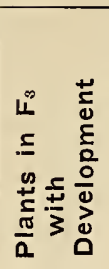 } & L & न Nम \\
\hline & + & 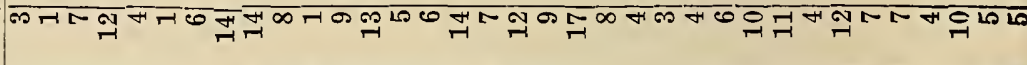 \\
\hline & m & 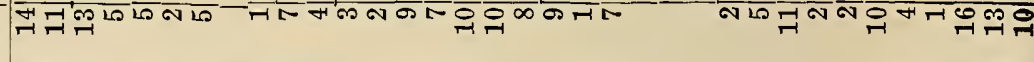 \\
\hline & a & 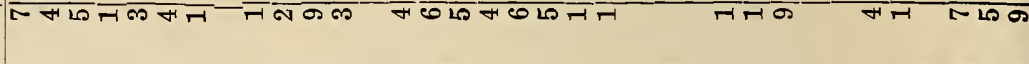 \\
\hline \multirow{2}{*}{$\dot{0} \quad \frac{5}{3}$} & - & 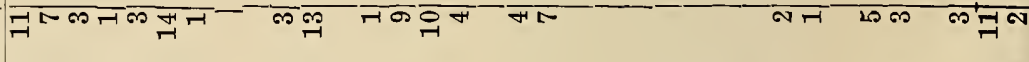 \\
\hline & - & LOR \\
\hline \multicolumn{2}{|c|}{ 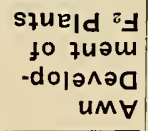 } & 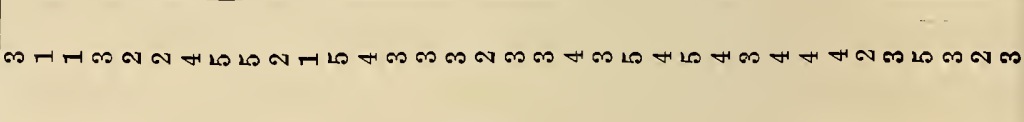 \\
\hline \multirow{2}{*}{ 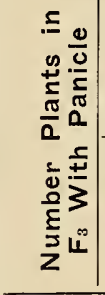 } & $\frac{0}{0}$ & 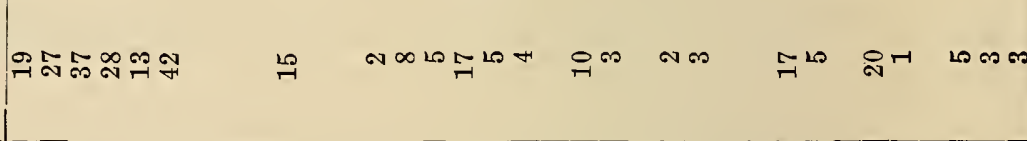 \\
\hline & 咅 & అన స్ำ \\
\hline \multicolumn{2}{|c|}{ 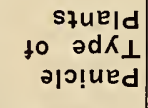 } & UNUNUNUUNO00000000000000000000U0000000 \\
\hline \multirow{2}{*}{ 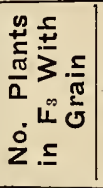 } & \multirow{2}{*}{$\begin{array}{l}\frac{0}{\frac{ \pm}{c}} \\
3 \\
\frac{5}{0} \\
\frac{\pi}{m}\end{array}$} & HN \\
\hline & & 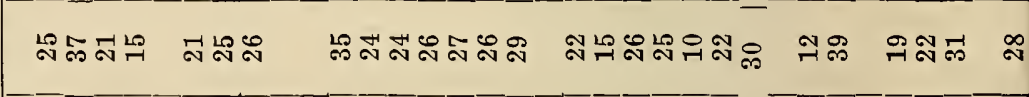 \\
\hline \multicolumn{2}{|c|}{ 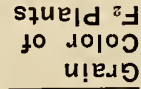 } & 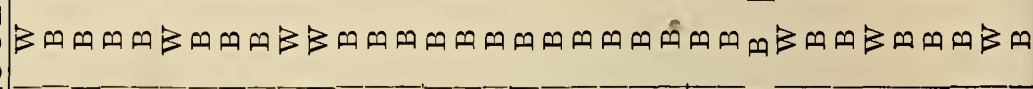 \\
\hline $\begin{array}{l}\dot{z} \\
\dot{I} \\
\dot{z}\end{array}$ & & 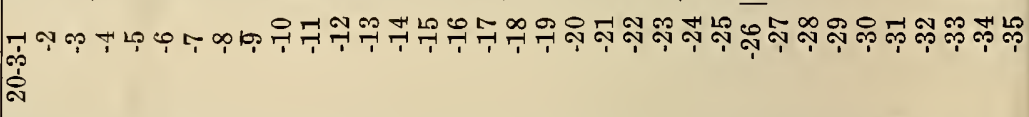 \\
\hline 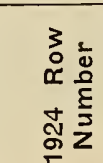 & & 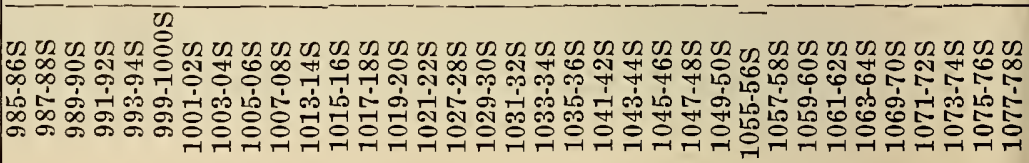 \\
\hline
\end{tabular}




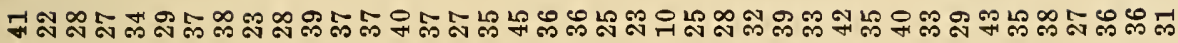

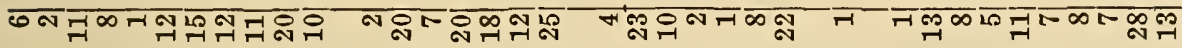

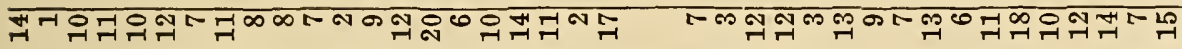

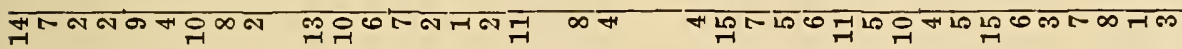

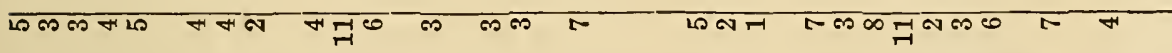

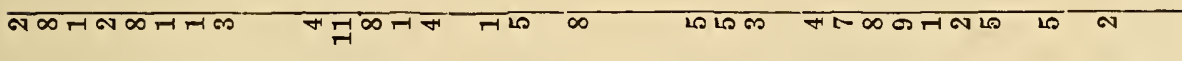

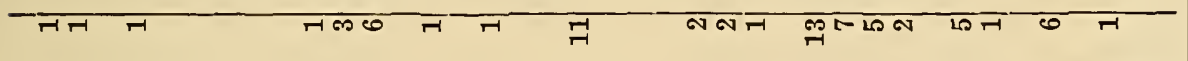

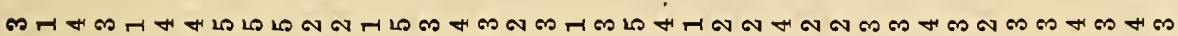
os $\underset{H}{H}$
$\infty \quad$ Lo
$\operatorname{loN}$ क
$\operatorname{LON}$
$\infty \pi \infty$
๑)

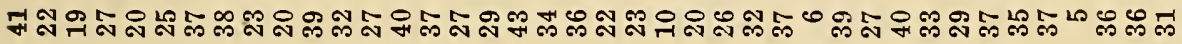
0000000000000000000000000000000000000000

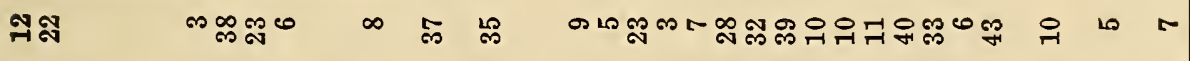

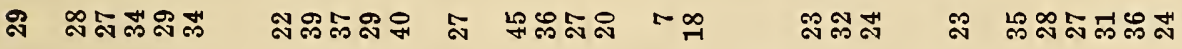

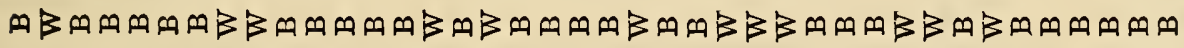
勿

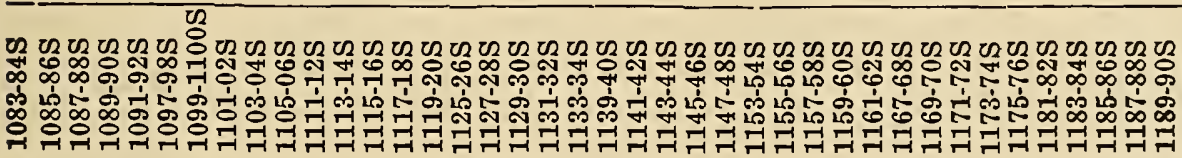




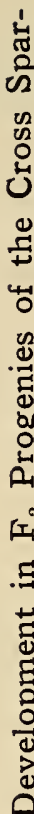

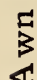

它

ग्ञ

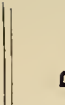

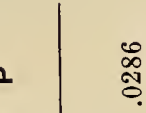

(n)

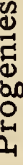

x"

.

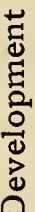

结

$+$

葛

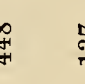

$\stackrel{\circ}{\circ} \stackrel{\infty}{\circ}$

\&

है

㟧

뭉

(1)

๓

웅

芩

ఖี

离

5

要

列

is

m

디

+ L

T1

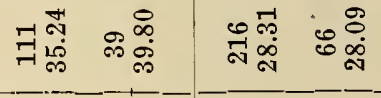

$\frac{5}{3}$

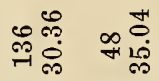

10.

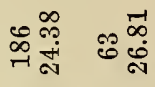

:

ஜํㅛ

- ———-

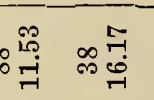

$r$

以

-

\begin{tabular}{|c|c|}
\hline 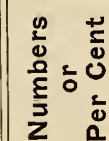 & 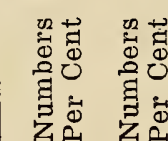 \\
\hline
\end{tabular}

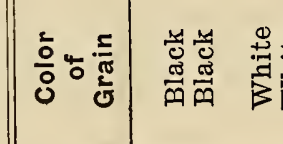

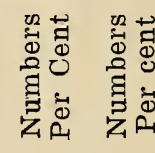

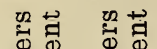

О

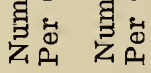

$\rightarrow$

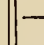

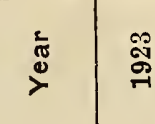

号

मे

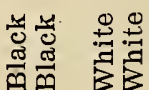

븡 붕

लि हB

E 


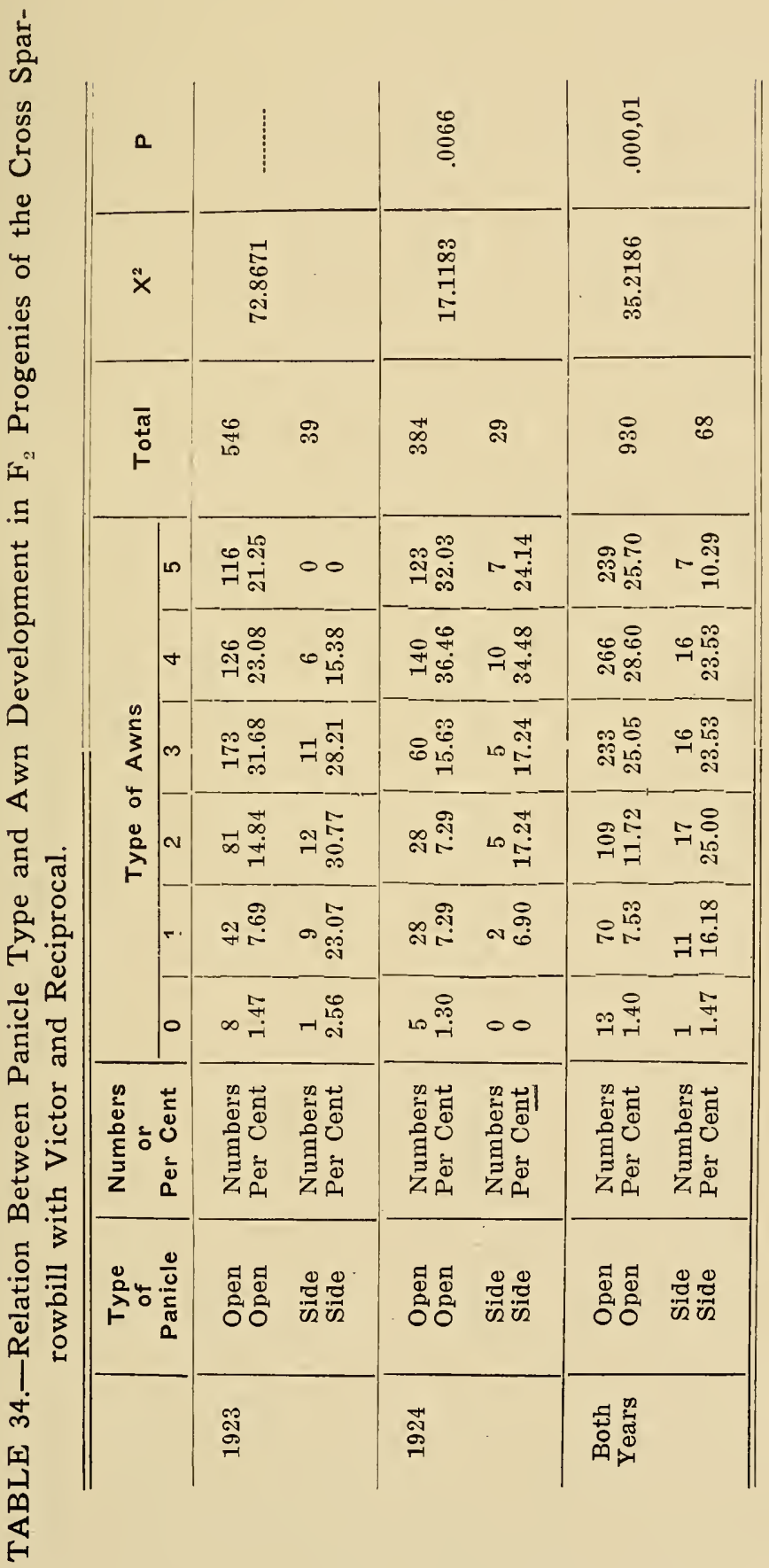






\section{HECKMAN \\ BINDERY INC.}

\section{JUNE 99}


